
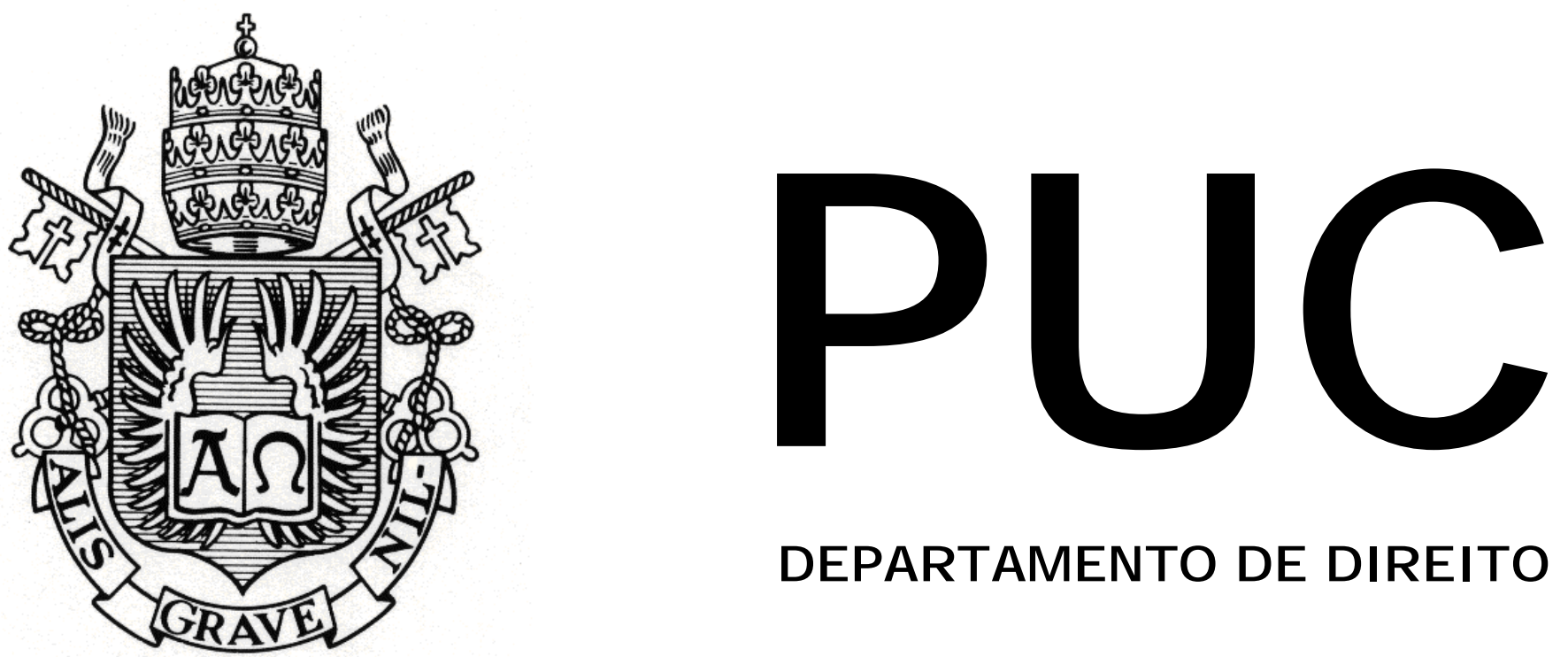

DEPARTAMENTO DE DIREITO

\title{
UMA VISÃO JURÍDICO-ECONÔMICA DO ARTIGO 254-A DA LEI N. 6.404/76
}

por

GABRIELLE SANTOS CORDEIRO

ORIENTADOR(A): JULIAN FONSECA PEÑA CHEDIAK

2009.1

PONTIFÍCIA UNIVERSIDADE CATÓLICA DO RIO DE JANEIRO

RUA MARQUÊS DE SÃO VICENTE, 225 - CEP 22453-900

RIO DE JANEIRO - BRASIL 


\title{
UMA VISÃO JURÍDICO-ECONÔMICA DO ARTIGO 254-A DA LEI N. 6.404/76
}

\author{
por \\ GABRIELLE SANTOS CORDEIRO
}

Monografia apresentada ao Departamento de Direito da Pontifícia Universidade Católica do Rio de Janeiro (PUC-Rio) para a obtenção do Título de Bacharel em Direito.

Orientador(a): JULIAN FONSECA PEÑA CHEDIAK 


\begin{abstract}
À minha querida Mami e querido Tonio, por tamanha dedicação na minha formação e por me ensinarem a dar valor às coisas realmente importantes, com todo meu amor.
\end{abstract}




\section{Agradecimentos}

À minha família, por me darem todo conforto e afeto do mundo.

Ao Danielzinho, pela sua paciência e carinho.

Aos meus queridos amigos do colégio, da faculdade e do Motta, pelo companheirismo e pelos momentos de diversão.

Ao Julian, meu orientador, pelos valiosos comentários, e especial contribuição na minha formação pessoal e profissional.

Obrigada. 


\section{Resumo}

CORDEIRO, Gabrielle Santos, Uma Visão Jurídico-Econômica do Artigo 254-A da Lei n. 6.406/76. 87f. Monografia (Graduação em Direito) Pontifícia Universidade Católica do Rio de Janeiro. Rio de Janeiro, 2009.

O presente trabalho busca demonstrar a importância de se avaliar os efeitos das normas jurídicas no campo econômico. Qualquer decisão de intervir na ordem econômica deve se fundamentar na análise dos custos e benefícios, a fim de se buscar a alocação eficiente dos recursos. Tendo isto em vista, a intervenção só será aceitável quando os ganhos totais obtidos para a sociedade forem superiores aos ganhos obtidos quando as forças do mercado atuam livremente.

O artigo 254-A da LSA tem por objetivo econômico proteger os minoritários, em especial, da apropriação pelo controlador de benefícios inerentes ao controle, já que esta proteção aumentaria a confiança dos investidores no mercado de capitais, o que reduziria o custo para captação de recursos pelas companhias nesse mercado, promovendo o desenvolvimento econômico. Contudo, o mecanismo adotado pela LSA não é adequada à proteção dos minoritários, além de possuir diversas ineficiências prejudiciais a este desenvolvimento. Em vez de se exigir o compartilhamento do prêmio de controle pelo controlador, reputa-se mais adequado e eficiente um mecanismo de proteção capaz de coibir diretamente condutas que representem a apropriação de benefícios em detrimento do minoritário, associado a regras de transparência e a uma fiscalização eficaz.

Verificar-se-á, portanto, sob a perspectiva do desenvolvimento do mercado de capitais, que os ganhos obtidos pela livre atuação das forças do mercado são mais eficientes se comparados aos resultados desta intervenção. 
Palavras Chave: Direito e Economia - Regulação Econômica - Eficiência Direito de Venda Conjunta - Poder de Controle - Acionista Controlador Acionista Minoritário - Alienação de Controle - Benefícios Privados do Controle - Prêmio de Controle. 


\section{Abstract}

CORDEIRO, Gabrielle Santos, Uma Visão Jurídico-Econômica do Artigo 254-A da Lei n. 6.406/76. 87f. Monografia (Graduação em Direito) Pontifícia Universidade Católica do Rio de Janeiro. Rio de Janeiro, 2009.

This paper aims to portray the importance of assessing the effects brought upon the economic sphere by legal rules and regulations. Any and all decision to intervene in the economy must always be founded on an analysis of the costs and benefits related to it, striving to encounter an efficient allocation of the resources. In this sense, an intervention shall only be acceptable when the total profit to society is greater than the benefits brought upon circumstances where the market was able to act in a free and autonomous manner.

The primary purpose of Article 254-A of the Brazilian Corporate Law is the protection of minority shareholders, in particular, from the extraction of private benefits of control, since these protections would increase investors' reliability in the capital market, which, in turn, would lead to a reduction of firms' cost of equity capital. However, the mechanism adopted by the Brazilian Corporate Law not only does not adequately protect minority shareholders, but it also has several inefficiencies harmfully impacting in the capital market. Instead of requiring the share of the control premium by the controlling shareholder, it is more appropriate and efficient to establish a mechanism that directly prevents the extraction of private benefits by the controlling shareholders, alongside with rules of disclosure and an effective inspection.

In view of those aspects, it will be shown that under the perspective of capital market development, the total results obtained by the market rules are more efficient when compared to the results of such intervention. 
Key Words: Law and Economics - Economic Regulation - Efficiency Tag Along - Control Power - Controlling shareholder - Minority shareholder - Sales of Controlling Block - Private Benefits of Control Control Premium. 


\section{Sumário}

Introdução ............................................................................................11

CAPÍTULO 1 - REGULAÇÃO ESTATAL DA ECONOMIA ......................15

1.1. Fundamentos da Regulação Econômica...................................15

1.2. Limites Constitucionais à Atuação Estatal na Economia................23

\section{CAPÍTULO 2 - DIREITO DE VENDA CONJUNTA NO ORDENAMENTO}

BRASILEIRO ...............................................................................28

2.1. Histórico do direito de venda conjunta no Direito Brasileiro .......28

2.2. Poder de Controle nas Sociedades Anônimas...........................33

2.3. Destinatários da Oferta .....................................................39

2.4. Prêmio de Controle ...............................................................40

2.5. Aplicação do artigo 254-A da LSA ....................................44

CAPÍTULO 3 - O DIREITO DE VENDA CONJUNTA NA ORDEM ECONÔMICA .....................................................................................29

3.1. Noções Gerais ......................................................29

3.2. Efeitos Econômicos do Direito de Venda Conjunta da LSA .......56

3.2.1. Benefícios e Custos Privados do Controle.........................56

3.2.2. Direito de Retirada ..................................................... 71

3.2.3. Afinal, o direito de venda conjunta na forma do artigo 254-A da LSA é eficiente?.....................................................................72

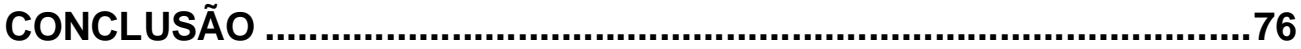

Referências Bibliográficas ..............................................................80 


\section{Principais Abreviaturas Utilizadas}

LSA - Lei n. 6.404 de dezembro de 1976, conforme alterada

Instrução CVM n. 361 - Instrução CVM n. 361, de 5 de março de 2002, conforme alterada

CVM - Comissão de Valores Mobiliários 


\section{Introdução}

A relação entre Direito e Economia, embora cada vez mais estreita, ainda é muito pouco reconhecida nas análises de questões tanto de natureza jurídica como econômica. Isso porque historicamente juristas e economistas têm enfoques diferentes.

Nesse sentido, vale transcrever observação do prêmio Nobel de Economia de 1982, George Stigler:

"Enquanto a eficiência constitui-se o problema fundamental dos economistas, a justiça é a preocupação que norteia os homens do direito (...). É profunda a diferença entre uma disciplina que procura explicar a vida econômica (e, de fato, todo o comportamento racional) e outra que pretende alcançar a justiça como elemento regulador de todos os aspectos da conduta humana. Esta diferença significa, basicamente, que o economista e o jurista vivem em mundos diferentes e falam diferentes línguas."1

Nas últimas décadas, o chamado movimento Law and Economics, embora ainda pouco desenvolvido no Brasil, vem ganhado cada vez mais espaço no âmbito internacional.

O avanço deste movimento se dá, principalmente, diante do reconhecimento da relevância da convergência desses dois campos para explicar a evolução da sociedade, fomentar o desenvolvimento econômico e social e o ambiente de negócios. A aproximação desses campos permite,

\footnotetext{
${ }^{1}$ Law or Economics?, The Journal of Law and Economics, v. 35, n. 2, p. 462-3, out 1992. ("If efficiency is the fundamental problem of economists, justice is the guiding beacon of law professors. (...) The difference between a discipline that seeks to explain economic life (and, indeed, all rational behavior) and a discipline that seeks to achieve justice in regulating all aspects of human behavior is profound. This difference means that, basically, the economist and the lawyer live in different worlds and speak different languages").
} 
ainda, trabalhar as dimensões da eqüidade social e da eficiência econômica de modo equilibrado. ${ }^{2}$

Desta forma, é fundamental que essas duas áreas saiam do isolamento e se convirjam para, em conjunto, cooperarem para o desenvolvimento do país.

Partindo das premissas de que os recursos são escassos e que os agentes econômicos buscam racionalmente maximizar o seu bem-estar, conclui-se que estes agentes responderão a incentivos, os quais podem se corporificar de diversas formas, inclusive, de normas jurídicas (decisões judiciais ou leis). Observa-se, assim, que, no mundo dos fatos, as normas jurídicas influenciam diretamente as relações econômicas e sociais.

Diante disto, é fundamental a percepção de que arranjos institucionais não são neutros em relação ao uso dos recursos econômicos e que as decisões judiciais que buscam fazer justiça desdobram-se em efeitos sobre a eficiência econômica. ${ }^{3}$

Os juristas devem, portanto, abandonar a tradicional visão purista do Direito, e adotar esse raciocínio econômico-jurídico, pautando-se, em especial, na noção de eficiência. Ou seja, devem valer-se da análise dos custos e benefícios, de modo que uma norma só deve ser implantada se produzir um resultado final mais benéfico do que o obtido sem a sua aplicação

Nesse contexto, o presente trabalho tem por escopo identificar os efeitos da obrigação consubstanciada no artigo 254-A da LSA, bem como

\footnotetext{
${ }^{2}$ In Direito \& Economia : Análise Econômica do Direito e das Organizações, Organização Decio Zylbersztajn e Rachel Sztajn, Rio de Janeiro, Ed. Elsevier, 2005, Apresentação, VI.

${ }^{3}$ Farina, Elizabeth M. M. Q., in Direito \& Economia : Análise Econômica do Direito e das

Organizações, op. cit., Prefácio.
} 
seus custos e benefícios, para avaliar em que medida seu resultado será eficiente, de forma a contribuir para o desenvolvimento econômico e social do país.

O artigo 254-A prevê a obrigação de realizar oferta pública no caso de alienação de controle de companhia aberta para a aquisição das ações dos acionistas minoritários por, pelo menos, o equivalente a $80 \%$ do preço pago pelas ações integrantes do bloco de controle.

O objetivo basilar desta norma é garantir proteção aos acionistas minoritários nas alienações de controle, conferindo-lhes o direito de alienar suas ações em condições equânimes.

A proteção dos minoritários desempenha um papel importante para o desenvolvimento do mercado de capitais, visto que a confiança dos investidores reduz diretamente o custo para a captação de recursos, incentivando-se novas emissões de valores mobiliários pelas companhias, com o conseqüente desenvolvimento econômico.

Todavia, é essencial que o raciocínio econômico-jurídico também seja utilizado para a criação de normas protetoras sob o risco de se obter um resultado indesejado.

Para a análise do referido artigo, o Capítulo 1 dedica-se a expor os principais fundamentos da regulação econômica, analisados sob a ótica do estudo da eficiência do artigo 254-A da LSA.

No Capítulo 2 far-se-á um breve resumo histórico do tratamento dado pelo ordenamento jurídico brasileiro às alienações de controle, até a inclusão do artigo 254-A pela Lei n. 10.303/01. Em seguida, serão abordados as principais questões e conceitos que envolvem este artigo, 
quais sejam, o conceito de controle e seus desdobramentos, as discussões acerca da definição dos destinatários da oferta, bem como a forma pela qual o artigo 254-A pôs fim a elas, e o polêmico conceito de prêmio de controle. Por fim, será demonstrado como o artigo 254-A vem sendo aplicado na prática.

E, finalmente, no Capítulo 3, será exposto o complexo movimento histórico que antecedeu a concepção do tag along, e os seus reflexos no Brasil. Serão demonstrados, ainda, os principais efeitos econômicos da obrigação de realizar oferta pública nos termos do artigo 254-A, para verificar-se se o referido artigo alcança seus objetivos e se este mecanismo é economicamente eficiente. 


\section{CAPÍTULO 1 - REGULAÇÃO ESTATAL DA ECONOMIA}

\subsection{Fundamentos da Regulação Econômica}

A regulação econômica ${ }^{4}$ é um tema controverso, por limitar a liberdade dos agentes no processo de tomada de decisões no campo econômico. Trata-se de um fenômeno multifacetado e complexo, em que o estudo interdisciplinar torna-se essencial para compreendê-lo.

Nesse sentido, aos juristas cabe aceitar que o Direito não é um mundo à parte, pois interfere em todas as atividades humanas, inclusive na economia. Aos economistas cabe entender que as políticas econômicas se desenvolvem dentro de marcos institucionais e de regras estabelecidas em um Estado de Direito. Os ganhos dessa associação são mútuos, demonstrando a necessidade de se abandonar o isolamento, na tentativa de unificar alguns conceitos, por meio de um diálogo entre esses dois campos.

A partir desse diálogo, o Direito passa a valer-se de um conjunto de princípios econômicos a serem considerados em decisões judiciais e na elaboração de normas. A adoção desses princípios para fins da análise econômica de atos jurídicos é de suma importância para a evolução do Direito, bem como para sua legitimação frente à sociedade e às necessidades sociais. Diante disto, a introdução da noção de eficiência no Direito revela-se condição sine quo non para o progresso econômico e para a boa aplicação da justiça.

Como bem explica ARNOLD WALD, citando Alain Minc, "Economia e Direito se complementam, pois 'o direito sem o mercado é a

\footnotetext{
${ }^{4}$ Importante distinguir regulação econômica da social. A última compreende áreas de meioambiente, condições de trabalho, relações de consumo, entre outras.
} 
imobilidade ou paralisia da sociedade', enquanto 'o mercado sem o direito é o caos"." 5

A discussão, basicamente, remonta na função do mercado, entendido como o ambiente onde os agentes se encontram para estabelecer relações comerciais. Se, por um lado, sua função basilar é servir como instrumento à alocação eficiente de recursos e, com isso, promover o desenvolvimento econômico; por outro, em razão dos seus efeitos nas relações sociais, encontra limites e regulamentações que têm por fundamento valores sociais de justiça e eqüidade. Diante desse conflito, indaga-se como buscar tais valores sociais sem coibir o desenvolvimento econômico.

De um lado, defende-se, com base no interesse social, a intervenção do Estado para corrigir práticas comerciais ineficientes e não-eqüitativas, como a concorrência imperfeita, assimetria de informação, externalidades e mercados ausentes (e.g. serviços de saúde). Nessa linha, há, inclusive, estudos indicando que a melhoria da eqüidade contribui para um desenvolvimento sustentável de longo prazo, maximizando o potencial do crescimento econômico. ${ }^{6}$

No outro extremo, sustenta-se ser muito mais benéfico para a sociedade um mercado funcionando livremente, porque em uma grande sociedade aberta - em si uma ordem espontânea - o seu bom funcionamento será garantido pela autonomia das pessoas, exercida com base em seus interesses pessoais guiados pela mão invisivel ${ }^{7}$ do mercado. ${ }^{8}$

\footnotetext{
${ }^{5}$ PINHEIRO, Armando Castelar; SADDI, Jairo, Direito, Economia e Mercados, Rio de Janeiro, Elsevier, 2005, $2^{a}$ reimpressão, Prefácio, XXII.

${ }^{6}$ Conforme posição manifestada por Joseph Stiglitz na conferência Financiamento Latinoamericano e o Papel dos Bancos de Desenvolvimento realizada nos dias 30 e 31 de março de 2006, na Assembléia Anual do BID, em Belo Horizonte.

${ }^{7}$ Mão invisível foi um termo introduzido por Adam Smith em "A Riqueza das nações" para descrever como, numa economia de mercado, apesar da inexistência de uma entidade coordenadora do interesse comunal, a interação dos indivíduos parece resultar numa determinada ordem, como se houvesse uma mão invisível que os orientasse.
} 
Questiona-se, portanto, a existência de falhas de mercado e, mesmo as admitindo, defender-se-ia a sua correção pelo sistema de mercados de maneira mais eficientes que se deixadas ao cuidado do Estado. ${ }^{9}$

Ambas as teorias têm suas limitações. Em um mercado perfeito ${ }^{10} \mathrm{e}$ de agentes racionais os recursos serão sempre eficientemente alocados, porém não necessariamente eqüitativos e, ademais, há interesses sociais que dificilmente seriam alcançados senão mediante ação estatal (e.g. educação e saúde acessíveis a todos). Paralelamente, o modelo político-econômico intervencionista, com atuações extensivas nos resultados dos mercados, não obstrui resultados ineficientes.

É inegável a existência de falhas de governo, como mostram diversos estudos sobre o tema que comparam, por exemplo, a eficiência do governo e do setor privado em atividades similares - tais como a coleta do lixo - sugerindo que o setor público é sistematicamente menos eficiente do que o setor privado. ${ }^{11}$ A influência dos lobbies e das pressões políticas também podem causar distorções relevantes nas ações do governo, como destaca DOUGLASS NORTH, prêmio Nobel de Economia em 1993:

"The dilemma is a straightforward one. The government is not a disinterested party in the economy. By the very nature of the political process (...), the government has strong incentives to behave opportunistically to maximize the

\footnotetext{
${ }^{8}$ ARAGÃO, Alexandre Santos de. Agências Reguladoras e a Evolução do Direito Administrativo Econômico. Rio de Janeiro: Forense, 2006, p. 46-54.

${ }^{9}$ Cf. UBIRATAN, Iorio J., "Falhas de Mercado" versus Falhas de Governo. Disponível em: <http://www.ubirataniorio.org/material.htm>. Acesso em 30 de março de 2009.

${ }^{10}$ De acordo com Mankiw, mercado perfeito seria aquele em que as forças da oferta e demanda se encontram num ponto de equilíbrio em que há maximização da soma dos excedentes para ambas as partes (produtores e consumidores). (MANKIW, N. Gregory, Introdução à economia: princípios de micro e macroeconomia, Rio de Janeiro, Campus, 1999, p. 150-6).

${ }^{11}$ Cf. AFONSO, António; SCHUKNECHT, Ludger, TANZI, Vito, Public sector efficiency: an international comparison. ECB Working Paper No. 242, 2003, disponível em: <http://www.ecb.int/pub/pdf/scpwps/ecbwp242.pdf>, acesso em 20 de abril de 2009. MANDL, Ulrike, DIERX, Adriaan, ILZKOVITZ, Fabienne, The efficiency and effectiveness of public spending, Economic and Financial Affairs, Economic Paper n. 301, 2008, disponível em: $<$ http://ec.europa.eu/economy_finance/publications/publication11902_en.pdf>, acesso em 20 de abril de 2009. MURPHY, Warren, Efficiency (and effectiveness) in the public sector, Nova Zelândia, 2007, disponível em: <http://www.conferenz.co.nz/efficiency-and-effectiveness-in-thepublic-sector-2.html>, acesso em 20 de abril de 2009. GERSHON, Peter, Gershon Efficiency Review, 2004-5.
} 
rents of those with access to the government decision-making process. In some cases this means that the government is, in effect, a kleptocracy; in other cases it means that government will cartelize economic-activity in favor of politically influential parties. In rare cases the government designs and enforces a set of rules of the game that encourage productive activity." 12

Além disso, o setor público enfrenta restrições orçamentárias que o impedem de contratar os melhores funcionários nas diferentes funções. Finalmente, o governo não está imune às imperfeições de informação. Muitos programas governamentais destinados a resolver um tipo de problema acabam criando outros (e.g. controle de preços, controles de taxas de juros, de salários e de câmbio, concessão de seguro-desemprego).

Em segundo lugar, o processo de decisões coletivas do Estado democrático tem suas deficiências, levando algumas vezes a decisões equivocadas, quando não ao imobilismo. Situações que exigem ação rápida podem sofrer com este processo decisório, acarretando custos à sociedade. Se um indivíduo toma a frente e decide por conta própria, a decisão poderá ser eficiente, mas não será democrática. A esse respeito, ALEXANDRE ARAGÃO, in verbis:

"Não é possível a adoção de um modelo político-econômico único em uma sociedade na qual existem diversas concepções reciprocamente excludentes, todas elas legítimas e protegidas pelo Direito. O Estado, ao contrário da administração econômica dos pequenos grupos homogêneos, deverá dar conta da pluralidade de concepções existentes no seio da sociedade. Noutras palavras, a decisão a respeito de como se dará a atuação do Estado no seio da sociedade (por exemplo, se mediante uma atuação empresarial estatal direta, ou através da regulação das empresas privadas), é questão que está sujeita ao processo político pluralista e democrático. (...) Estas características do Estado Democrático de Direito se revelam ainda mais relevantes perante a economia, que, via de regra, possui maior dinamismo que o direito, o que faz com que a ordem econômica constitucional deva ser particularmente maleável às necessidades econômicas e

\footnotetext{
${ }^{12}$ Understanding the Process of Economic Change, New Jersey, Princeton University Press, 2005, p. 67. ("Este é um dilema simples. O governo não é uma parte desinteressada na economia. Pela própria natureza do processo político (...), o governo tem fortes incentivos para maximizar o passe daqueles que têm acesso ao processo decisório do governo. Em alguns casos isso significa que o governo é, efetivamente, uma 'cleptocracia', em outros casos significa que o governo vai cartelizar a atividade econômica em favor de partes politicamente influentes. Em raras ocasiões o governo cria e implementa regras do jogo que estimulem a atividade produtiva.” Tradução livre).
} 
posições políticas majoritárias em cada momento, respeitados, naturalmente, o núcleo protegido contra tais contingências."13

Em vista disso, deve-se buscar um equilibro entre essas teorias, para que seja possível conciliar crescimento econômico e desenvolvimento social, cabendo ao Estado, assim, preservar os valores sociais (essencialmente a eqüidade) sem inibir o progresso econômico.

Um meio eficaz para alcançar tais objetivos é o desenvolvimento de uma base institucional sólida, como, aliás, defende MANCUR OLSON, segundo o qual "qualquer país pobre que implemente políticas econômicas e instituições relativamente adequadas experimenta uma rápida retomada do crescimento". 14

Para DOUGLASS NORTH, as instituições - em sua acepção "regras do jogo em uma sociedade" - afetam diretamente o desempenho econômico. ${ }^{15}$ Segundo o economista, num mercado em que as informações fossem integralmente disponibilizadas, as instituições não seriam necessárias. Contudo, num mercado de informações assimétricas e de relações impessoais, as instituições exercem um papel fundamental por criarem mecanismos de acesso a elas e de coerção para o cumprimento dos contratos (enforcement), reduzindo substancialmente os custos de transação. ${ }^{16}$ As instituições, por estruturarem as relações humanas por meio de incentivos, são capazes de determinar comportamentos, reduzindo as incertezas e promovendo a competitividade do mercado. ${ }^{17}$

\footnotetext{
${ }^{13}$ Op. cit., p. 56-7.

${ }^{14}$ Distinguished lecture on Economics in government. Big bills left on the sidewalk: why some nations are rich, and others poor. Journal of Economic Perspectives, n. 10, n. 2, primavera, 1996. Disponível em: <http://www.fbird.com/assets/MancurOlson_on_Transition_Econ_732003152238.pdf>. Acesso em 5 de abril de 2009.

${ }^{15}$ Institutions, Institutional Change and Economic Performance, Cambridge University Press, New York, 1990, p. 3.

${ }^{16}$ Ibid., p. 57-8.

${ }^{17}$ Ibid., p. 4.
} 
Recentes trabalhos liderados por SHAHID BURKI e GUILLERMO PERRY $^{18}$ e EDWARD GLAESER et. al., ${ }^{19}$ demonstraram, empiricamente, a influência positiva das instituições legais eficientes sobre a economia. Esses trabalhos ressaltam o papel das leis sob diversos aspectos, dentre eles, (i) na alocação de direitos de propriedade maximizando o impacto dos custos de transação sobre a eficiência econômica; (ii) na definição da distribuição da renda em geral; (iii) na função dos contratos em organizar a produção por meio do mercado (em anteposição a fazê-lo hierarquicamente dentro da empresa) e em distribuir os riscos entre os agentes econômicos; e (iv) do Judiciário em arbitrar disputas no caso de situações não previstas em contratos (ou na lei). ${ }^{20}$

Essa relação entre instituições (legais ou judiciais) e comportamentos humanos se fundamenta na noção de que, diante da escassez de recursos, os agentes econômicos buscam racionalmente maximizar seu bem-estar e, deste modo, reagem a incentivos ou desincentivos, que podem assumir a forma tanto de preços, como de leis, decisões judiciais, dentre outras ações estatais. Em outras palavras, num mundo de recursos escassos, se há a possibilidade de aumento do bem-estar de um agente econômico pela mudança de seu comportamento, possivelmente ele o mudará.

RONALD H. COASE, prêmio Nobel de Economia de 1991, precursor nos estudos sobre a importância das instituições para o desenvolvimento econômico, demonstrou que a intervenção estatal na ordem econômica, em certos casos, reduz os custos de transação a ponto de se obter resultados (totais) mais eficientes do que se deixada à sorte da livre iniciativa. Isso porque os Estados seriam como "super-empresas" (super-

\footnotetext{
${ }^{18}$ Beyond the Washington consensus: institutions matter, Washington, World Bank Publications, 1998.

${ }^{19}$ GLAESER, Edward, LA PORTA, Rafael, SILANES, Florêncio Lopez de, e SHLEIFER Andrei, Do institutions cause growth?, Disponível em:

$<$ http://papers.ssrn.com/sol3/papers.cfm?abstract_id=556370>. Acesso em 2 de abril de 2009.

${ }^{20}$ PINHEIRO, Armando Castelar; SADDI, Jairo, Op. cit., p. 11-2.
} 
firms), pois, ao influenciarem o uso dos fatores de produção, coordenariam suas atividades, reduzindo custos de transação. ${ }^{21}$

Entretanto, os custos incorridos pela regulação de uma atividade econômica podem ser muito altos se consideradas todas as conseqüências (não apenas econômicas) decorrentes da intervenção estatal, de modo que muitas vezes será mais eficiente optar-se pela auto-regulação, ${ }^{22}$ como acentua RONALD COASE:

"It is clear that governmental has powers which might enable it to get some things done at lower cost than a private organization (or at any rate one without special governmental powers). But governmental administrative machine is not itself costless. It can, in fact, on occasion be extremely costly. Furthermore, there is no reason to suppose that restrictive and zoning regulations, made by a fallible administration subject to political pressures and operating without any competitive check, will necessarily always be those which increase the efficiency with which the economic system operates. (...) it follows that direct governmental regulation will not necessarily give better results than leaving the problem to be solved by the market or the firm. But equally there is no reason why, on occasion, such governmental administrative regulation should not lead to an improvement in economic efficiency., 23

Assim, a decisão de intervir na economia deve considerar fundamentalmente os ganhos totais obtidos para a sociedade, sendo certo que, apenas quando importar em redução de custos, ela será justificável.

RACHEL SZTAJN, analogamente, sustenta que:

"Uma das funções de qualquer regulação, independentemente de como se justifique a regulação, é melhorar, aperfeiçoar a vida em sociedade, que se

\footnotetext{
${ }^{21}$ The Problem of Social Cost, Journal of Law and Economics, 1960, p. 9. Disponível em: <http://www.sfu.ca/ allen/CoaseJLE1960.pdf>. Acesso em 15 de abril de 2009.

${ }^{22}$ Nas palavras de Coase: "What has to be decided is whether the gain from preventing the harm is greater than the loss which would be suffered elsewhere as a result of stopping the action which produces the harm." (Ibid., p. 11.)

${ }^{23}$ Ibid., p. 9. ("É claro que o governo tem poderes que o habilitam a realizar certas coisas a custo inferior que o de uma organização privada (ou, de qualquer forma, que não mediante poderes governamentais especiais). Mas a máquina administrativa governamental não é, em si, sem custo. Pode, na verdade, ser extremamente custosa em algumas situações. Além disso, não há razão para supor que a regulação restritiva e setorizada, desenvolvida por uma administração falível, sujeita a pressões políticas e que opera sem qualquer controle competitivo, vai necessariamente sempre ser aquela que aumenta a eficiência com a qual o sistema econômico opera. (...) Portanto, a regulação não vai necessariamente gerar melhores resultados do que deixar que o problema seja resolvido pelo mercado ou pela companhia. Mas, do mesmo modo, não há razão para que, por vezes, esta regulação não possa levar a uma melhora na eficiência econômica.” Tradução livre).
} 
mensura de várias formas: uma delas é a relação custo-benefício, meramente econômica, que deve ser analisada em função dos benefícios para parcelas majoritárias da população contra os custos impostos a todos ou a alguns". ${ }^{24}$

A noção de eficiência ${ }^{25}$ vai muito além de meros efeitos econômicos, representando condição não só para o progresso econômico como para o social. A sua incorporação revela-se fundamental por permitir uma análise do resultado final ${ }^{26}$ e evitar que numa situação de imperfeição, a intervenção produza um resultado pior do que a situação original, como alerta RONALD COASE:

"Analysis in term of divergences between private and social products concentrates attention on particular deficiencies in the system and tends to nourish the belief that any measure which will remove the deficiency is necessarily desirable. It diverts attention from those other changes in the system which are inevitably associated with the corrective measure, changes which may well produce more harm than the original deficiency."27

$\mathrm{Na}$ esteira da tendência internacional, o Brasil deveria adotar a análise dos custos e benefícios ao propor novas normas ${ }^{28}$ e mesmo com relação às normas já existentes, com o objetivo de impedir e superar intervenções ineficientes.

Conclui-se que, para o progresso econômico e social, especialmente no Brasil, arraigado por uma cultura ainda paternalista e clientelista, é fundamental que a antinomia entre regular e desregular se desassocie de

\footnotetext{
${ }^{24}$ SZTAJN, Rachel. Teoria Jurídica da Empresa. Atividade Empresária e Mercados. São Paulo: Atlas, 2004, p. 52.

${ }^{25} \mathrm{Na}$ concepção de Kaldor-Hicks, eficiência significa obter o máximo de resultado possível com o menor nível de custos possível. Essencialmente, esta é a técnica da análise do custo-benefício.

${ }^{26}$ Coase ensina que "when an economist is comparing alternative social arrangements, the proper procedure is to compare the total social product yielded by these different arrangements." (Op. cit., p. 17).

${ }^{27}$ Ibid., p. 21. (“A análise da diferença entre os resultados privados e sociais atrai a atenção para deficiências particulares do sistema e tendem a nutrir a idéia de que qualquer medida que remove uma deficiência é necessariamente desejável. Esta noção desvia a atenção daquelas outras mudanças no sistema que estão inevitavelmente associadas à medida coercitiva, as quais podem gerar mais danos do que a deficiência original." Tradução livre).

${ }_{28}$ A título de exemplo, vale conferir o trabalho de Lawrence Schwartz, Cost-Benefit Analysis in Canadian Securities Regulation. Disponível em: <http://www.tfmsl.ca/docs/V4(6)\%20Schwartz.pdf>. Acesso em 5 de abril de 2009.
} 
questões de cunho essencialmente político para se aproximar às discussões acerca da natureza do processo econômico decorrente de uma intervenção.

\subsection{Limites Constitucionais à Atuação Estatal na Economia}

A Constituição atribui ao Estado a função de agente normativo e regulador da atividade econômica, ${ }^{29}$ estabelecendo que a livre iniciativa ${ }^{30}$ deverá se harmonizar com os objetivos de valorização do trabalho humano, da existência digna e da justiça social. ${ }^{31}$

Criou-se uma estrutura complexa de princípios aparentemente inconciliáveis, impondo-se à atividade reguladora do Estado a manutenção da liberdade econômica (livre concorrência) bem como a implementação de objetivos de interesse geral (ex. pleno emprego, desigualdade social), sem prescindir da liberdade de iniciativa. ${ }^{32}$

Na prática, a regulação econômica será delineada de acordo com a relevância econômica do setor e com os interesses envolvidos. Entretanto, se a regulação não tivesse de observar limites, o campo de atuação do particular na economia poderia ser drasticamente reduzido, erradicando a liberdade de iniciativa, essencial à ordem econômica.

\footnotetext{
29 “Art. 174. Como agente normativo e regulador da atividade econômica, o Estado exercerá, na forma da lei, as funções de fiscalização, incentivo e planejamento, sendo este determinante para o setor público e indicativo para o setor privado."

30 “Art. $1^{\circ}$ A República Federativa do Brasil, formada pela união indissolúvel dos Estados e Municípios e do Distrito Federal, constitui-se em Estado Democrático de Direito e tem como fundamentos: I - a soberania; II - a cidadania; III - a dignidade da pessoa humana; IV - os valores sociais do trabalho e da livre iniciativa; V - o pluralismo político." (grifou-se)

31 “Art. 170. A ordem econômica, fundada na valorização do trabalho humano e na livre iniciativa, tem por fim assegurar a todos existência digna, conforme os ditames da justiça social, observados os seguintes princípios: (...)" (grifou-se)

${ }^{32}$ MARQUES NETO, Floriano Peixoto de Azevedo. Limites à Abrangência e à Intensidade da Regulação Estatal. Revista de Direito Público da Economia, Número 4, Salvador, 2005-6, p. 74-5. Disponível em: < http://www.direitodoestado.com/revista/REDAE-4-NOVEMBRO-2005FLORIANO_AZEVEDO.pdf>. Acesso em 5 de abril de 2009.
} 
Esses limites podem ser extraídos da própria leitura do texto constitucional (e.g. caput do artigo $37,{ }^{33}$ bem como outros princípios explícitos e implícitos relativos à estruturação da ordem econômica, no artigo 170 e seguintes). São, basicamente, dois os princípios que balizarão os limites do Estado na intervenção da ordem econômica: o princípio da subsidiariedade e o princípio da proporcionalidade

Nos termos do princípio da subsidiariedade, as restrições à livre iniciativa são admitidas apenas quando houver razões suficientemente relevantes e sua finalidade for resguardar o interesse público.

Este princípio se fundamenta na suposição de que as instituições sociais prescindem do Estado para resolver a maioria de seus problemas resultantes do convívio social, de sorte que a necessidade de intervenção estatal seria residual, só eficiente para situações-limite. Sobre o assunto, o Professor FLORIANO DE AZEVEDO MARQUES NETO oportunamente adiciona:

“(...) o manejo da autoridade estatal só se põe aceitável, porquanto necessária, na medida em que uma finalidade de interesse geral (tanto a dirimição de um conflito, como a promoção do bem comum) não seja alcançável autonomamente pelas instituições sociais. Por certo, é através deste raciocínio que se permite divisar as fronteiras entre a atuação do Estado (necessária, mas não necessariamente pretendida) e o campo de liberdade e autonomia dos indivíduos (entendido como um bem em si). ${ }^{, 34}$ (grifou-se).

A subsidiariedade pressupõe a autonomia dos agentes econômicos (sejam empresas, unidades federativas ou indivíduos) para buscar seus próprios interesses e objetivos e, por conseqüência, atingir as finalidades sociais. A intervenção estatal só se justificará quando estes entes não forem capazes de, autonomamente, atender estas finalidades.

\footnotetext{
33 “Art. 37. A administração pública direta e indireta de qualquer dos Poderes da União, dos Estados, do Distrito Federal e dos Municípios obedecerá aos princípios de legalidade, impessoalidade, moralidade, publicidade e eficiência (...)" (grifou-se).
} 
Acerca do referido princípio, FERNANDO PIMENTEL CINTRA enfatiza:

\begin{abstract}
"Não há dúvida de que o princípio da subsidiariedade regula a intervenção do Estado na Economia. Sendo esta uma atividade essencialmente privada, o Estado, cuja função é buscar o bom comum e da justiça distributiva, não tem competência originária de atuação. Se ele deve corrigir distorções e para tanto intervir, isto deve ser feito em nome do bem comum e da justiça distributiva e não em razão da maior ou menor eficácia das sociedades inferiores. A função subsidiária do Estado em matéria econômica é uma 'função autentica e natural' e não simplesmente uma 'fórmula pragmática'. Em outros termos, a subsidiariedade é intrínseca à função do Estado em matéria econômica. $" 35$ (grifou-se)
\end{abstract}

A limitação da ação reguladora do Estado imposta por este princípio abrange não apenas a regulação mediante atos administrativos, mas também a própria prerrogativa do legislador de constituir campos de incidência específicos de regulação quando isto não for sustentável por ausência dos elementos necessários à sua legitimação. VITAL MOREIRA, jurista português, esclarece que:

“(...) na teoria da regulação jurídica o princípio da subsidiariedade significa fundamentalmente o <<princípio da subsidiariedade legislativa $>>$, implicando uma postura de autoconcentração ou de auto-restrição legislativa do Estado e de devolução de poderes regulatórios para estruturas não estaduais de autoregulação." 36

O princípio da proporcionalidade, outro limitador da ação estatal sobre o domínio econômico, opera no momento em que a atuação estatal ocorre, contendo arbítrios e prescrevendo a moderação do exercício desse poder.

O referido princípio impede o Poder Público de empregar meios desproporcionais à obtenção de determinados fins, de forma que não seria lícito o uso de medidas restritivas ou a formulação de exigências aos particulares que vão além do estritamente necessário para a realização

\footnotetext{
${ }^{34}$ Ibid., p. 80.

${ }^{35} \mathrm{O}$ princípio da subsidiariedade no direito administrativo. Dissertação (Mestrado). Apud Ibid., p. 82.

${ }^{36}$ Auto-regulamentação profissional, Coimbra, Almedina, 1997, p. 98.
} 
daquele fim. O Poder Público, assim, deverá sempre optar, dentre as medidas aptas a atingir o objetivo desejado, aquela menos gravosa ao indivíduo sujeito ao poder estatal, pesando as desvantagens dos meios em relação às vantagens dos fins. ${ }^{37}$

Com relação à abrangência desse princípio, em julgamento no âmbito do Conselho Administrativo de Defesa Econômica (CADE), o Conselheiro RONALDO PORTO MACEDO JR. manifestou-se no sentido de que "o princípio da proporcionalidade de certo modo condiciona o exercício das funções legislativa, executiva e judicial, visando impedir abusos, excessos ou interpretações desarrazoadas que possam violar os direitos constitucionalmente consagrados". 38

O princípio da proporcionalidade não vincula apenas a atividade estatal na esfera da Administração Pública, mas também a sua função judicante e legislativa, ou seja, funcionará como crivo de controle tanto da competência normativa (edição de leis, regulamentos, ou outros atos) quanto da competência material (atos de efeitos concretos).

No campo econômico, este princípio auxiliará na avaliação acerca da necessidade e adequação à restrição do acesso à exploração de uma dada atividade econômica em sentido amplo, bem como na ponderação e moderação dos ônus e condicionantes que venham a se impor ou exigir do particular como condição de acesso à exploração de determinada atividade.

A presença do Estado na ordem econômica pode trazer resultados muito positivos para o desenvolvimento econômico, desde que esta atuação tenha limites rígidos, sob pena de anular os seus benefícios.

\footnotetext{
${ }^{37}$ MARQUES NETO, Floriano Peixoto de Azevedo, op. cit., p. 89.

${ }^{38}$ Cf. voto no Processo Administrativo n. 08000.022579/97-05, Representante Messer Grieshem do Brasil Ltda., Representada: White Martins.
} 
Ambos os princípios, subsidiariedade e proporcionalidade, portanto, limitam a abrangência e a intensidade da atividade regulatória, e devem ser utilizados com prudência e parcimônia, justamente para que a atuação regulatória seja eficaz aos fins pretendidos. 


\section{CAPÍTULO 2 - DIREITO DE VENDA CONJUNTA NO ORDENAMENTO BRASILEIRO}

Denomina-se tag along, ou direito de venda conjunta, a faculdade concedida aos acionistas minoritários de alienarem suas ações conjuntamente, no caso da alienação de controle de uma sociedade. Este instituto jurídico dá ensejo a controvérsias universais e intermináveis. No Brasil, em especial, a controvérsia é tão profunda que ao longo da história da LSA, o instituto passou por três momentos absolutamente distintos.

Os principais debates giram em torno das definições de controle, de acionista controlador e minoritário, bem como da definição e caracterização de alienação de controle. Estes pontos serão abordados a seguir, logo após um breve histórico do tag along no ordenamento brasileiro.

\subsection{Histórico do direito de venda conjunta no Direito Brasileiro}

Notava-se, antes da Lei n. 6.404/76, uma preocupação do governo no sentido de garantir um tratamento igualitário entre os acionistas controladores e os demais acionistas, como se depreende da Exposição de Motivos CDE-14 de 25 de junho de 1974, elaborada pelos Ministros da Fazenda e do Planejamento e da ideologia contida no PND II, ao estabelecer, como um dos objetivos da reforma da lei societária, a previsão de mecanismos que impedissem que cada ação do majoritário possuísse valor de mercado superior a cada ação do minoritário. ${ }^{39}$

Todavia, ao contrário das orientações manifestadas, o texto do Anteprojeto revisto apresentado ao Ministro da Fazenda e por este transmitido ao Presidente da República por exposição de 24 de junho de 1976 (projeto original) se limitou a garantir tratamento igualitário aos

\footnotetext{
${ }^{39}$ CARVALHOSA, Modesto. A Nova Lei das Sociedades Anônimas, Rio de Janeiro, Ed. Paz e Terra. 1976, p. 129.
} 
acionistas minoritários nas transferências de controle de companhias abertas que dependessem de autorização do governo para funcionar. O objetivo dessa regra era evitar que, nestes casos, o valor dos intangíveis (carta-patente) incorporado no preço do bloco de controle não fosse compartilhado entre todos os acionistas.

Depois de revisto pelo Conselho de Desenvolvimento Econômico, em 27 de junho de 1976, o Anteprojeto foi enviado ao Congresso Nacional acompanhada de exposição de motivos elaborada pelos seus autores. Com relação às alienações de controle, a exposição de motivos dispunha da seguinte forma:

\section{“Seção VI}

\section{Alienação de Controle}

O Projeto regula a alienação de controle de companhias abertas, a partir das considerações a seguir resumidas:

a) toda economia de mercado atribui valor econômico ao controle da companhia, independentemente do valor das ações que o asseguram; o valor das ações resulta dos direitos, que conferem, de participação nos lucros e no acervo líquido da companhia, enquanto que o de controle decorre do poder de determinar o destino da empresa, escolher seus administradores e definir suas políticas;

b) a transferência do controle, qualquer que seja o preço de negociação das ações, não acarreta, em princípio, agravo a direito de minoritário; mas se a compra efetivar-se por companhia que, a seguir, promova a incorporação da controlada, do fato pode resultar flagrante prejuízo para a minoria, tanto da incorporada quanto da incorporadora: com a extinção da companhia controlada, deixa de existir o controle adquirido, e os acionistas minoritários da controladora (dependendo das bases da incorporação) suportam parte do custo de aquisição do controle Mais ainda: em regra, todo o valor do controle da companhia incorporada, ou ao menos parte dela, acresce ao valor do controle da incorporadora, isto é, resulta em benefício do seu acionista controlador;

c) os exemplos das vendas de controle de instituições financeiras, que apresentam circunstâncias peculiares, não devem servir de justificativa para normas gerais que pretendam negar o valor de mercado do controle; no entanto, é inegável que o critério - muitas vezes adotado entre nós - de considerar o valor dos intangíveis das instituições financeiras como pertencente ao acionista controlador, e não a todos os seus acionistas, na proporção da participação no capital social, conflita com os fundamentos do direito societário;

d) o Projeto reconhece a realidade do poder do acionista controlador, para atribuir-lhe responsabilidades próprias, de que não participam os acionistas minoritários; seria, pois, incoerente se pretendesse, para efeito de transferência 
desse poder, negar a sua existência ou proibir o mercado de lhe atribuir valor econômico." (grifou-se)

O Deputado Tancredo Neves, relator da Comissão de Economia, apresentou parecer opinando sobre o projeto e comentando cada uma das emendas apresentadas. Especificamente quanto àquelas relacionadas às alienações do controle, rejeitou todas que visavam garantir ao minoritário direito de participar no preço da venda das ações de propriedade do acionista controlador, pois qualquer restrição legal ao direito de propriedade do acionista controlador conflitaria com a natureza e com as características dessa espécie de sociedade que explicam o seu sucesso e a sua eficiência como modelo de organização. Defendeu, ainda, que a lei, mediante regulação estrita, deve impedir uma alienação do controle apenas quando prejudicial aos demais acionistas. $^{40}$

Apesar da opinião desfavorável do relator e contra a vontade dos autores do projeto, $^{41}$ a pressão do legislativo prevaleceu e a emenda proposta pelo deputado Otto Lehman, conhecida como "Emenda Lehman", foi aprovada na forma do artigo $254 .^{42}$ A emenda subordinava a alienação de controle da companhia aberta à prévia autorização da CVM, incumbida de zelar pelo tratamento igualitário a ser conferido aos minoritários,

\footnotetext{
${ }^{40}$ LAMY FILHO, Alfredo; PEDREIRA, José Luiz Bulhões. A lei das S.A. (pressupostos, elaboração, aplicação), vol. 1, Rio de Janeiro, Renovar, 1997, p. 268-9.

${ }^{41}$ Os autores manifestaram-se contra a emenda, alegando que adotavam a proposição insustentável de que a venda das ações do controle de uma sociedade anônima pode ser causa de "prejuízos" para os acionistas que não vendem suas ações. Para eles, a transferência de controle da sociedade, por si só, não afeta o direito desses acionistas, embora a compra por preço exagerado possa ser causa de prejuízos para os acionistas da companhia que compra. A possibilidade de prejuízo para todos os minoritários - tanto da compradora quanto da companhia cujo controle é vendido somente surge no momento da incorporação da controlada pela controladora (Cf. LAMY FILHO, Alfredo; PEDREIRA, José Luiz Bulhões, Op. cit., p. 286).

${ }^{42}$ Com a seguinte redação: "Art. 254. A alienação do controle da companhia aberta dependerá de prévia autorização da Comissão de Valores Imobiliários. § $1^{\circ}$ A Comissão de Valores Mobiliários deve zelar para que seja assegurado tratamento igualitário aos acionistas minoritários, mediante simultânea oferta pública para aquisição de ações. $§ 2^{\circ}$ Se o número de ações ofertadas, incluindo as dos controladores ou majoritários, ultrapassar o máximo previsto na oferta, será obrigatório o rateio, na forma prevista no instrumento da oferta pública. $\S 3^{\circ}$ Compete ao Conselho Monetário Nacional estabelecer normas a serem observadas na oferta pública relativa à alienação do controle de companhia aberta."
} 
mediante a realização de simultânea oferta pública para aquisição de suas ações.

Este artigo foi intensamente criticado por conter diversas imprecisões, como a dúvida com relação à abrangência do direito de tratamento igualitário (se incluía preferencialistas, ou se se dirigia apenas aos ordinaristas), e à sua extensão nos casos de alienação indireta.

Em 5 de maio de 1997, durante a implementação de um programa de privatizações, foi editada a Lei n. 9.467, responsável pela extinção de diversos direitos dos minoritários. Dentre estes direitos, a referida lei revogou o artigo 254 com o objetivo de facilitar as reestruturações societárias evitando que os antigos controladores (União e Estados) dividissem o prêmio de controle com os demais acionistas. ${ }^{43}$ Sobre a revogação deste artigo, os professores ALFREDO LAMY FILHO e JOSÉ LUIZ BULHÕES PEDREIRA se manifestaram no seguinte sentido:

\begin{abstract}
“A medida é salutar e deverá concorrer para aumentar o número das companhias abertas, dado que o artigo 254 (que subordinava a alienação de controle a autorização da CVM para o fim de assegurar oferta pública aos minoritários) representou grave empecilho à abertura das companhias: é que os controladores das companhias fechadas hesitavam em recorrer ao mercado para o aumento de capital das suas empresas sabendo que, caso o fizessem, as ações que detinham passavam a ter ônus diferente das demais. Esses efeitos haviam sido agravados pela interpretação extensiva que a CVM deu ao dispositivo, não obstante à Resolução CMN n. 401/76 que regulamentou, ao aplicá-lo aos casos de alienação de controle de 'holding' de companhia aberta."
\end{abstract}

Após a onda das privatizações, iniciou-se uma forte pressão pelo retorno de uma legislação que protegesse os interesses dos minoritários, resultando numa nova reforma da lei societária, com a edição da Lei n. 10.303/01. Esta reforma reintroduziu, por meio do artigo 254-A, a

\footnotetext{
${ }^{43}$ A justificativa explicitada pelo governo para a extinção do artigo 254 foi a de que tal regra elevava os custos de aquisição de controle de modo ineficiente, desviando recursos que poderiam ser mais bem utilizados na capitalização da companhia.

${ }^{44}$ Op. cit., p. 329.
} 
sistemática do antigo artigo 254, com algumas alterações importantes, passando a viger da seguinte forma:

"Art. 254-A. A alienação, direta ou indireta, do controle de companhia aberta somente poderá ser contratada sob a condição, suspensiva ou resolutiva, de que 0 adquirente se obrigue a fazer oferta pública de aquisição das ações com direito a voto de propriedade dos demais acionistas da companhia, de modo a lhes assegurar o preço no mínimo igual a $80 \%$ (oitenta por cento) do valor pago por ação com direito a voto, integrante do bloco de controle.

$\S 1^{0}$ Entende-se como alienação de controle a transferência, de forma direta ou indireta, de ações integrantes do bloco de controle, de ações vinculadas a acordos de acionistas e de valores mobiliários conversíveis em ações com direito a voto, cessão de direitos de subscrição de ações e de outros títulos ou direitos relativos a valores mobiliários conversíveis em ações que venham a resultar na alienação de controle acionário da sociedade.

$\S 2^{\circ}$ A Comissão de Valores Mobiliários autorizará a alienação de controle de que trata o caput, desde que verificado que as condições da oferta pública atendem aos requisitos legais.

$\S 3^{\circ}$ Compete à Comissão de Valores Mobiliários estabelecer normas a serem observadas na oferta pública de que trata o caput.

$\S 4^{\circ} \mathrm{O}$ adquirente do controle acionário de companhia aberta poderá oferecer aos acionistas minoritários a opção de permanecer na companhia, mediante o pagamento de um prêmio equivalente à diferença entre o valor de mercado das ações e o valor pago por ação integrante do bloco de controle." (grifou-se)

Em 2002, a CVM editou a Instrução CVM n. 361, que regula as ofertas públicas de aquisição de ações de companhia aberta, dentre elas, a oferta pública por alienação de controle.

Cabe, por fim, ressaltar a existência de uma forte tendência à criação de regras ainda mais rigorosas às alienações de controle. Em dezembro de 2000, a Bovespa criou segmentos de listagem destinados à negociação de ações emitidas por companhias que se comprometam, voluntariamente, a adotar práticas de governança corporativa adicionais em relação às exigidas pela legislação.

No âmbito de negociação das companhias listadas no Nível 2, exigese a extensão a todos os detentores de ações ordinárias das mesmas 
condições obtidas pelos controladores na venda do controle e de, no mínimo, 70\% deste valor aos detentores de ações preferenciais. No Novo Mercado, por sua vez, exige-se a extensão das mesmas condições obtidas pelos controladores a todos os acionistas.

Atualmente, encontra-se em andamento uma revisão às regras do Novo Mercado que deve ser concluída até o final do primeiro semestre deste ano. Dentre as mudanças sugeridas, está a inclusão da exigência de realização de oferta pública para aquisição de ações quando um investidor adquirir uma participação relevante no capital social de uma companhia listada neste segmento. A sugestão predominante até o momento é de que a oferta pública deve ocorrer quando a aquisição corresponder a $30 \%$ das ações em circulação.

\subsection{Poder de Controle nas Sociedades Anônimas}

A compreensão do conceito de controle é fundamental para a definição do controlador, destinatário de uma série de deveres e responsabilidades do controlador, bem como para a identificação de uma alienação do controle para fins da aplicação do artigo 254-A. De acordo com o professor FÁBIO KONDER COMPARATO, ${ }^{45}$ o termo controle:

\footnotetext{
“(...) se origina do francês, surgindo em 1367, sob grafia contrerole, para indicar um rolo, ou registro, que servia para a verificação de outro registro. A acepção primitiva do vocábulo era, portanto, de fiscalização, e é este o seu sentido primeiro em francês até hoje. Na língua inglesa, porém, o termo assumiu o sentido de governo, de dominação, e mesmo de repressão."
}

\footnotetext{
${ }^{45}$ COMPARATO, Fábio Konder, Aspectos Jurídicos da Macroempresa, São Paulo, Editora Revista dos Tribunais, 1970, p. 71.
} 
O Dicionário Aurélio ${ }^{46}$ traz, dentre outras, as seguintes definições:

"1. Ato, efeito ou poder de controlar; domínio, governo.

2. Fiscalização exercida sobre as atividades de pessoas, órgãos, departamentos, ou sobre produtos, etc., para que tais atividades, ou produtos, não se desviem das normas preestabelecidas.

3. Restr. Fiscalização financeira.

4. (...)

5. Autodomínio físico e psíquico. (...)"

Como se observa, o sentido da palavra controle, em português, foi influenciado tanto pelo francês como pelo inglês. Entretanto, as nossas leis se aproximaram mais da concepção inglesa, utilizando seu sentido de disciplina ou regulação. ${ }^{47}$

$\mathrm{Na}$ esfera das sociedades anônimas, o legislador discriminou poderes-funções considerados fundamentais, atribuindo-os a órgãos próprios: (i) o poder-função deliberante à assembléia geral, (ii) o poderfunção administrativo à diretoria e (iii) o poder-função sindicante ao conselho fiscal. Cada órgão, embora dotado de poderes próprios, não se coloca no mesmo nível, organizando-se hierarquicamente. ${ }^{48}$

A definição do poder de controle nas sociedades anônimas será sempre verificada em função da assembléia geral, por ser dela, em última instância, que emanarão as decisões. ${ }^{49}$ À primeira vista, pode parecer que o titular do poder de controle seriam sempre os acionistas. No entanto, considerar a assembléia geral como órgão supremo, admitindo que suas

\footnotetext{
${ }^{46}$ Dicionário Aurélio Eletrônico Século XXI, Versão 3.0 - Novembro de 1999.

${ }^{47}$ Como exemplos de utilização dessa acepção, citam-se (i) a Lei Delegada n. 4/62 que declara tratar da intervenção da União do domínio econômico, para estabelecer o "controle do abastecimento", (ii) a Lei n. 8.884/94, que em seu artigo $20, \S 2^{\circ}$, reconhece a existência de posição dominante quando uma empresa ou grupo de empresas controla parcela substancial de mercado relevante como fornecedor, intermediário, adquirente ou financiador de um produto, serviço ou tecnologia a ele relativa; e (iii) a Lei n. 4.595/64 que atribuía ao Banco Central do Brasil a competência privativa para exercer o controle dos capitais estrangeiros, nos termos da lei. ${ }^{48}$ COMPARATO, Fábio Konder; SALOMÃO FILHO, Calixto. O Poder de Controle na Sociedade Anônima, $5^{\text {a }}$ edição, São Paulo, Ed. Forense, 2008, p. 30-1.

${ }^{49} \mathrm{Na}$ forma do artigo 121 da LSA que estabelece que "a assembléia geral, convocada e instalada de acordo com a lei e o estatuto, tem poderes para decidir todos os negócios relativos ao objeto da companhia e tomar as resoluções que julgar convenientes à sua defesa e desenvolvimento”.
} 
deliberações obedecem a uma disciplina semelhante à das eleições populares, significa encobrir a realidade do poder de controle. Sua realidade é, na verdade, mais complexa, e demonstra que o poder de controle pode ser exercido de outras formas.

Nesse sentido, o professor FÁBIO KONDER COMPARATO explica que "o controle manifesta-se através dos poderes decisórios da assembléia de acionistas como necessária legitimação do seu exercício. Mas

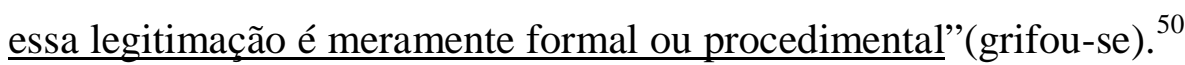

TULLIO ASCARELLI, atento a esta problemática, define poder de controle como "a possibilidade de uma ou mais pessoas imporem a sua decisão à assembléia da sociedade". 51

Diante dos diferentes regimes legais e da diversidade que caracteriza as sociedades anônimas, é possível reconhecer a existência de duas formas de exercício do poder de controle: interno e externo.

No exercício externo, o controle pertence a um ou mais agentes que atuam de fora, isto é, quando se tem uma situação em que tais agentes exercem uma influência dominante nos assuntos sociais (e.g., credores da sociedade ou por titulares de garantias reais sobre ativos da sociedade).

Já o controle interno é exercido quando o titular do controle atua no interior da sociedade. A princípio, ele deveria ser exercido pelos próprios acionistas, já que são eles que participam do risco (direto) do investimento. Nestes casos prevalece o princípio do majoritário, ou seja, numa assembléia geral, as decisões serão tomadas quando forem reunidos mais da metade dos votos.

\footnotetext{
${ }^{50}$ Ibid., p. 39.

${ }^{51}$ ASCARELLI, Tullio, Apud, Ibid., p.39.
} 
Entretanto, há diversos outros aspectos que dificultam a definição do controle interno. É possível, por exemplo, que os detentores da maioria dos votos não exerçam o controle efetivo, o que pode ocorrer, basicamente, em virtude de dois fatores: (i) pulverização do capital; e (ii) a falta de exercício dos direitos de votos de investidores institucionais. ${ }^{52}$

Em alguns casos estes fatores levam ao esvaziamento total dos poderes decisórios das assembléias gerais, de modo que ninguém é capaz de, individualmente, reunir a maioria dos votos, o que torna os administradores efetivos controladores da companhia, perpetuando-se na sua direção (controle gerencial).

Sobre o controle gerencial, o professor FÁBIO KONDER COMPARATO explica que "a perpetuação dos administradores no poder é obtida, sobretudo, com a utilização de complexos mecanismos de representação de acionistas em assembléia (proxy machinery), explorandose ao máximo o absenteísmo do corpo acionário". ${ }^{53}$

Em vista disso, TULLIO ASCARELLI conclui que "o controle não corresponde a uma situação jurídica determinada, mas a uma situação de fato, que pode derivar de várias relações jurídicas, levando-se em consideração não só o tipo de relação, como também as modalidades de fato correspondentes à situação comparativa dos diferentes interessados na vida da sociedade". ${ }^{44}$

\footnotetext{
${ }^{52}$ TESTA, Pedro. The Mandatory Bid Rule in the European Community and in Brazil: A Critical View, disponível em: 〈http://papers.ssrn.com/sol3/papers.cfm?abstract_id=943089>. Acesso em 3 de fevereiro de 2009.

${ }^{53}$ COMPARATO, Fábio Konder; SALOMÃO FILHO, Calixto, Op. cit., p. 72.

${ }^{54}$ Apud, Ibid, p. 47.
} 
A LSA não define expressamente o conceito de controle, contudo, o tangencia ao definir acionista controlador, conforme o disposto no artigo 116 e alíneas:

"Art. 116. Entende-se por acionista controlador a pessoa, natural ou jurídica, ou o grupo de pessoas vinculadas por acordo de voto, ou sob controle comum, que:

a) é titular de direitos de sócio que lhe assegurem, de modo permanente, a maioria dos votos nas deliberações da assembléia geral e o poder de eleger a maioria dos administradores da companhia; e

b) usa efetivamente seu poder para dirigir as atividades sociais e orientar o funcionamento dos órgãos da companhia."

$\mathrm{O}$ artigo 116 e alíneas permitem estabelecer as características do poder de controle. São elas: (i) maioria de votos nas deliberações da assembléia geral e o poder conseqüente de eleger a maioria dos administradores da companhia; (ii) asseguração dessa maioria em caráter permanente; e (iii) efetivo exercício desse poder para dirigir as atividades sociais e comandar os órgãos societários. ${ }^{55}$

O parágrafo terceiro do artigo 243 da LSA praticamente repete estas características ao considerar "controlada a sociedade na qual a controladora, diretamente ou através de outras controladas, é titular de direitos de sócio que lhe assegurem, de modo permanente, preponderância nas deliberações sociais e o poder de eleger a maioria dos seus administradores".

A diferença de terminologia entre maioria de votos $\mathrm{e}$ preponderância não tem relevância, se justificando apenas pelo fato de se admitir que a sociedade controladora, no grupo societário, não seja anônima.

\footnotetext{
${ }^{55}$ CLEMENTE JUNIOR, José Alberto. Oferta pública de aquisição de ações na alienação de controle de companhias abertas. Revista de Direito Mercantil, Industrial, Econômico e Financeiro n. 129. Malheiros Editores: 2003, p. 209.
} 
Como se depreende da leitura dos artigos acima, a LSA impôs a titularidade dos direitos de sócio para a definiçãa do acionista controlador, excluindo, portanto, os controles externo e interno gerencial deste conceito, e limitando-se a tratar do controle exercido por acionistas.

Ademais, nota-se que, para a definição do acionista controlador, a LSA não exigiu a propriedade de percentual mínimo de ações votantes. Destarte, um bloco minoritário pode se tornar controlador caso acumule as características discriminadas acima, o que, em princípio, só seria possível em companhias cujas ações fossem amplamente pulverizadas no mercado, incomuns no Brasil onde predominam as companhias com controle acionário concentrado.

Com relação à titularidade do poder de controle, a LSA reconhece os seguintes sujeitos: (i) um único acionista (pessoal natural ou jurídica); ou (ii) um grupo de sócios vinculados por acordo de acionistas. Sobre a matéria, NELSON CÂNDIDO MOTTA oportunamente ensina que:

\footnotetext{
"São, pois, duas situações distintas e inconfundíveis. Na primeira delas, o poder de controle é prerrogativa individual do sócio que sozinho detenha e exerça a faculdade de formar, nas assembléias gerais, a vontade da companhia; na segunda, o poder de controle é atributo coletivo de um grupo de sócios, vinculados entre si por acordo de acionistas, que sempre e necessariamente em conjunto deliberam e votam como um bloco, orgânico e unitário. (...)

O grupo de controle constitui, assim, uma unidade orgânica que tem perfil legal perfeitamente delineado. Constitui uma entidade do direito societário, com estrutura, funções e especificidades próprias. (...)

Cumpre reconhecer - por óbvio e evidente - que todos os acionistas que formam o grupo de controle, qualquer que seja a quantidade de ações de cada um, integram, todos eles, o bloco majoritário e ostentam, em conjunto, a condição de acionista controlador." ${ }^{56}$
}

\footnotetext{
${ }^{56}$ MOTTA, Nelson Cândido, Alienação e titularidade do poder de controle nas companhias abertas - Notas sobre a transferência de ações entre participantes do grupo controlador e sobre a interpretação do art. 254 da Lei das S.A., Revista Forense, v. 324, out-dez/1993, p. 82.
} 
Em virtude do caráter unitário do grupo de controle previsto pela LSA, transferências de ações realizadas, internamente, entre os sócios integrantes do grupo controlador, não alteram a titularidade do poder de controle.

\subsection{Destinatários da Oferta}

O extinto artigo 254 estabelecia que deveria ser dado tratamento igualitário aos acionistas minoritários mediante oferta pública para aquisição de ações. O critério de minoritários como destinatários da oferta dividia a opinião da doutrina no que diz respeito à sua abrangência.

Para LUIZ LEONARDO CANTIDIANO, "a noção de acionista minoritário representa um atributo que é mais qualitativo do que quantitativo, um status, cujo referencial necessário é o poder de controle e não o direito de voto". 57

Já para o professor ALFREDO LAMY FILHO, em parecer de 1987, “a dedução evidente da leitura do texto, é a de que se o controle está em função da maioria com direito a voto, obviamente a lei se referia à minoria de acionistas titulares de votos que, somados aos daquela maioria, são a totalidade dos que interferem na formação do controle". ${ }^{5}$

Malgrado a divergência de opiniões, a Resolução CMN n. 401/76, que regulamentou as alienações de controle, limitou a obrigação de ofertar apenas aos titulares de ações com direito a voto. ${ }^{59}$

\footnotetext{
${ }^{57}$ Alienação e Aquisição de Controle, RDM n. 59, 1985, p. 64.

${ }^{58}$ A lei das S.A. (pressupostos, elaboração, aplicação), vol. 2, Rio de Janeiro, Renovar, 1996, p. 683.

${ }^{59}$ De acordo com o inciso I da Resolução CMN n. 401, de 22 de dezembro de 1976, "a alienação do controle de companhia aberta somente poderá ser contratada sob a condição, suspensiva ou resolutiva, de que o adquirente se obrigue a fazer, nos termos desta Resolução, oferta pública de aquisição das ações com direito a voto de propriedade dos demais acionistas da companhia, de modo a lhes assegurar tratamento igualitário ao do acionista controlador."
} 
A redação do atual artigo 254-A pacificou, em termos, esta questão, ao estabelecer que a oferta se destinaria exclusivamente aos titulares de ações com direito a voto não integrantes do bloco de controle. Em termos porque remanesceu a dúvida sobre a inclusão dos detentores de ações preferenciais que adquiriram direito a voto ( $\S 1^{\circ}$ do artigo 111 da LSA) e de detentores de votos restrito (artigo 18 da LSA).

Com efeito, a Instrução CVM n. 361 restringiu a oferta aos titulares de ações com "pleno e permanente direito de voto", 60 excluindo ambas as hipóteses.

\subsection{Prêmio de Controle}

A aquisição do controle de uma companhia costuma ser precedida de um contrato celebrado entre o controlador e o adquirente do controle, em que se estabelece um preço pelo controle de determinada companhia. Este preço geralmente é superior ao valor de mercado que resultaria da soma das ações integrantes do bloco de controle se consideradas individualmente, por garantirem o exercício do poder de controle.

Esta diferença entre o valor conferido às ações pertencentes aos minoritários e as ações que integram o bloco de controle é usualmente denominada ágio ou prêmio de controle.

Como mencionado acima, a exposição de motivos da LSA já admitia a realidade do poder do acionista controlador para atribuir-lhe responsabilidades próprias de que não participam os minoritários, sendo, portanto, incoerente que se pretendesse, para efeito de transferência desse

\footnotetext{
${ }^{60}$ Artigo 29 da Instrução CVM n. 361 - "A OPA por alienação de controle de companhia aberta será obrigatória, na forma do art. 254-A da Lei 6.404/76, sempre que houver alienação, de forma direta ou indireta, do controle de companhia aberta, e terá por objeto todas as ações de emissão da companhia às quais seja atribuído o pleno e permanente direito de voto, por disposição legal ou estatutária."
} 
poder, negar sua existência ou proibir o mercado de lhe atribuir valor econômico.

A existência deste ágio no preço pago pelas ações integrantes do bloco de controle também é indiretamente admitida pelo caput do artigo 254-A. Do contrário, não faria sentido obrigar o adquirente do controle a realizar oferta pública para compra das demais ações por, no mínimo, $80 \%$ do preço pago pelas ações do controle.

Diversas são as teorias sobre a natureza deste ágio. Para ADOLPH BERLE JR. e GARDINER MEANS, o poder de controlar os negócios sociais seria um bem intangível pertencente à companhia, de forma que apenas a companhia poderia usufruir dos benefícios do controle, incluindo do prêmio que, portanto, deveria ser dividido entre todos os acionistas. ${ }^{61}$

Dentre os autores contemporâneos, ANDRÉA ANDREZO chega à conclusão similar. Segundo a autora, este ágio representaria o somatório dos seguintes elementos:

(i) prêmio de controle, entendido como o poder político de eleger a maioria dos administradores e orientar a condução dos negócios da companhia;

(ii) expectativa de resultados a serem obtidos a partir da condução dos negócios pelo novo controlador;

(iii) ativos não reconhecidos nas demonstrações contábeis, que pertencem à sociedade e não ao seu acionista controlador, tais como marcas, tecnologias, qualificação dos funcionários, dentre outros; e

\footnotetext{
${ }^{61}$ The Modern Corporation and Private Property, New York, Harcourt, Brace \& World, 4a edição, 1967 (originalmente publicado em 1932) Apud Pedro Testa, op. cit., p. 20.
} 
(iv) eventuais expropriações, ou seja, apropriações indevidas em benefício do controlador ou de terceiros e em detrimento dos acionistas não-controladores da companhia, tais como salários superiores aos de mercado, uso particular de bens da sociedade, empréstimos subsidiados, dentre outras.

Tendo em vista que: (a) o sobrepreço reflete outros fatores além do prêmio de controle; (b) os fatores que compõem esse sobrepreço estão relacionados também à contribuição de acionistas não controladores na formação do capital da companhia e na sua valorização; e (c) acionistas controladores e não controladores contribuem nas mesmas condições para a capitalização da companhia visto que não há diferença de preço na emissão entre ações a serem subscritas por tais acionistas, a autora conclui que todos os acionistas deveriam participar das vantagens pecuniárias no caso de uma alienação de controle. ${ }^{62}$

WILLIAM ANDREWS, baseado na tese de Berle e Means, desenvolveu sua teoria do princípio da igualdade de oportunidade (equal opportunity rule). Para o autor, o controlador poderia alienar suas ações pelo preço e nas condições que considerem adequados, desde que seja garantida, aos titulares de ações da mesma classe, a possibilidade de alienarem as suas nas mesmas condições oferecidas aos controladores. ${ }^{63} \mathrm{Ou}$ seja, na sua visão, o compartilhamento do prêmio se restringiria aos acionistas controladores e demais acionistas com direito a voto.

Em linha semelhante, MODESTO CARVALHOSA defende "que o acionista minoritário, embora normalmente não tome iniciativa de promover a capitalização da sociedade, empresta seu esforço para tal

\footnotetext{
${ }^{62}$ A alienação de controle de companhia aberta e a recente reforma da legislação societária efetivo avanço?, Revista de Direito Mercantil, Industrial, Econômico e Financeiro n. 130, Malheiros: 2003, p. 172-3.
} 
mister, (...); ademais, esse tipo de acionista experimenta os efeitos da política de autocapitalização da companhia, usualmente realizada pelo controlador. É, portanto, co-partícipe da valorização patrimonial da empresa, merecendo portanto tratamento igualitário, quando da alienação de seu controle". 64

NELSON EIZIRIK et. al., por sua vez, citam a doutrina internacional que alega que esta diferença de valor seria reflexo de uma insuficiente proteção aos minoritários, por permitir que os acionistas controladores se apropriem dos chamados benefícios privados do controle (private benefits of control), tais como empréstimos subsidiados e operações com partes relacionadas. Em razão da possibilidade de usufruto destes benefícios, paga-se um valor superior pela expectativa de que o controlador possa recuperar seu investimento por meio de expropriações indevidas de recursos da companhia. Por estas razões, este sobrepreço deveria ser compartilhado com os minoritários no momento da alienação de controle, impedindo que o controlador se aproprie de todo este sobrepreço. ${ }^{65}$

Com relação à nova sistemática do artigo 254-A, uma questão que desperta atenção relaciona-se ao preço a ser pago pelas ações dos minoritários. Diferentemente do artigo 254 que prescrevia o tratamento igualitário, o artigo 254-A exige que o valor a ser pago pelas ações dos minoritários equivalha a, pelo menos, $80 \%$ do valor pago pelas ações integrantes do bloco de controle.

\footnotetext{
${ }^{63}$ The Stockholder's Right to Equal Opportunity in the Sale of Shares, Harvard Law Review, n. 3, 1965.

${ }^{64}$ Apud LOBO, Jorge. Interpretação realista da alienação de controle de companhia aberta, p. 507.

${ }^{65}$ EIZIRIK, Nelson; GAAL, Ariádna B.; PARENTE, Flávia; HENRIQUES, Marcus de Freitas. Mercado de Capitais - regime jurídico. Rio de Janeiro, Renovar, 2008, p. 587.
} 
JOSÉ ALBERTO CLEMENTE JÚNIOR atribui essa mudança a uma valorização da responsabilidade do controlador acompanhada de uma mitigação do tratamento igualitário, admitindo-se que o controlador aproprie-se desse plus. ${ }^{66}$

Para ANDRÉA ANDREZO, “a legislação (...) consagra, expressamente, a diferença de valor entre ações do acionista controlador e dos acionistas não-controladores e estabelece a magnitude dessa diferença". 67

\subsection{Aplicação do artigo 254-A da LSA}

Por constituir um ônus bastante significativo para o adquirente do controle de uma companhia (quando não inviabilizar o negócio) e, ainda por conter algumas lacunas, na busca por segurança e previsibilidade, a interpretação do artigo 254-A da LSA deve ser a mais cautelosa e literal possível.

Em primeiro lugar, é preciso analisar os termos empregados pelo parágrafo primeiro do artigo 254-A, segundo o qual "entende-se como alienação de controle a transferência, de forma direta ou indireta, de ações integrantes do bloco de controle, de ações vinculadas a acordos de acionistas e de valores mobiliários conversíveis em ações com direito a voto, cessão de direitos de subscrição de ações e de outros títulos ou direitos relativos a valores mobiliários conversíveis em ações que venham a resultar na alienação de controle acionário da sociedade”.

De forma análoga, o parágrafo quarto do artigo 29 da Instrução CVM n. 361 define alienação de controle como "a operação, ou conjunto de operações, de alienação de valores mobiliários com direito a voto, ou neles

\footnotetext{
${ }^{66}$ Op.cit., p. 216.

${ }^{67}$ Op. cit., p. 168.
} 
conversíveis, ou de cessão onerosa de direitos de subscrição desses valores mobiliários, realizada pelo acionista controlador ou por pessoas integrantes do grupo de controle, pelas quais um terceiro, ou um conjunto de terceiros representando o mesmo interesse, adquira o poder de controle da companhia, como definido no art. 116 da Lei 6.404/76".

Observa-se que a acepção conferida à expressão alienação de controle é ampliada, vez que o critério definitivo é a aquisição do controle. Assim, as regras do artigo 254-A, caput e parágrafos (além da alienação direta) também abrangerão os casos de alienação indireta e de alienação em etapas em que não ocorre alienação de controle, desde que a operação, ao final, resulte em aquisição onerosa do controle acionário. ${ }^{68}$

A alienação direta do controle se caracteriza quando o acionista controlador ou grupo vinculado por acordo de acionista transfere o bloco de controle (ações que assegurem o poder de controle), passando o adquirente à posição de novo controlador. Constitui, na verdade, uma cessão de controle via negócio jurídico privado entre cedente e adquirente, cujo objeto é a alienação do bloco de controle. Significa dizer que o artigo 254-A será aplicável apenas às aquisições de controle derivadas, i.e., quando o adquirente substitui o antigo controlador, sucedendo-o em seus direitos, ficando os casos de aquisição originária - quando não há uma transferência onerosa $^{69}$ - fora do seu campo de incidência.

Nesse sentido, o artigo 254-A também não será aplicável àqueles casos em que o acionista controlador aliene parte das ações que compõem seu bloco de controle sem que esta alienação altere o controle (como, por

\footnotetext{
${ }^{68}$ CARVALHOSA, Modesto e EIZIRIK, Nelson. A Nova Lei das Sociedades Anônimas. São Paulo: Saraiva. 2002, p. 395.

${ }^{69}$ A aquisição originária do poder de controle pode ocorrer mediante (i) sucessivas aquisições de ações no mercado; (ii) oferta pública para aquisição do controle (na forma do artigo 257 da LSA); ou (iii) celebração de um acordo de acionistas por meio do qual determinados acionistas passam a deter, em conjunto, o controle da companhia (conforme o artigo 118 da LSA).
} 
exemplo, na hipótese de um controlador, que detenha $75 \%$ do capital votante, alienar $20 \%$ desse capital).

Já quando houver a transferência de ações vinculadas a acordo de acionista, em que um dos signatários ceda para um terceiro que passe a exercer posição dominante, CARVALHOSA e EIZIRIK admitem a aplicação da referida regra. ${ }^{70}$

Também não haverá incidência do artigo 254-A nos casos de transferências de ações no âmbito de um grupo controlador, devido ao caráter unitário do bloco de controle destacado acima.

Em suma, para a aplicação do artigo 254-A, não é necessário que o controlador aliene todas as suas ações ou valores mobiliários conversíveis em ações, nem que todos os integrantes do grupo de controle transfiram o conjunto das suas posições acionárias, bastando que a operação, em seu conjunto, resulte na alienação do controle acionário. ${ }^{71}$

Por último, para que se caracterize uma alienação de controle, o caráter oneroso do negócio jurídico deve estar presente. Ou seja, deve haver uma contraprestação, seja em dinheiro ou bens, em troca das ações ou valores mobiliários, mesmo que não haja ágio sobre o valor patrimonial, econômico ou de bolsa. ${ }^{72}$

Em consonância com as características indicadas acima, CARLOS AUGUSTO JUNQUEIRA DE SIQUEIRA define transferência de controle como:

“(...) a operação que resulta na efetiva substituição do poder de dominação na sociedade. É quando esse poder muda, efetivamente, de mãos, por qualquer

\footnotetext{
${ }^{70}$ Ibid., p. 398.

${ }^{71}$ CARVALHOSA, Modesto e EIZIRIK, Nelson, op. cit., p. 397.

${ }^{72} \mathrm{Na}$ forma do entendimento manifestado pela CVM no Parecer CVM/SJU n. 79/83.
} 
forma ou meio oneroso, fazendo incidir a obrigatoriedade de efetuar oferta pública de compra das ações pertencentes aos acionistas minoritários."73

ANDRÉA ANDREZO, por sua vez, enumera os requisitos que entende serem necessários para que fique caracterizada a alienação de controle, sendo eles:

(i) que a companhia tenha um controlador (a) titular de direitos de sócio que lhe assegurem, de modo permanente, a maioria dos votos nas deliberações da assembléia geral e o poder de eleger a maioria dos administradores, e (b) usa efetivamente seu poder para dirigir as atividades sociais e orientar o funcionamento dos órgãos da companhia;

(ii) a realização de negócio jurídico entre o controlador ou participante do grupo de controle e o terceiro adquirente do controle, que tenha por objeto a transferência do controle, realizado de uma única vez ou em etapas; e

(iii) que a companhia, no caso de alienação direta de controle, ou a sociedade que a controle, no caso de uma alienação indireta de controle, passe a ter novo controlador ou grupo de controle, em decorrência de negócio jurídico realizado com o controlador ou participante do grupo de controle anterior. ${ }^{74}$

Cumpre destacar a posição da CVM a respeito dos requisitos para que se configure a obrigação de realizar oferta pública pela alienação de controle. No julgamento do Processo Administrativo n. RJ-2008-4156, ${ }^{75}$ a CVM considerou como requisitos a ocorrência dos seguintes fatos: (i) que

\footnotetext{
${ }^{73}$ SIQUEIRA, Carlos Augusto Junqueira de. Transferência do controle acionário: interpretação e valor. Niterói, FMF, 2004, p. 64.

${ }_{75}^{74}$ Op. cit., p. 170.

${ }^{75}$ Processo julgado em 17 de junho de 2008, relativo à alienação de controle da Suzano Petroquímica S.A. à Petrobrás Brasileiro S.A.
} 
da operação, em seu conjunto, resulte o aparecimento de um terceiro como acionista controlador; (ii) transferência ou cessão, seja de ações, valores mobiliários, direitos de subscrição, ou outros títulos, i.e., deve haver uma transferência do controle das mãos do atual controlador para o novo controlador; e (iii) onerosidade, ou seja, é necessário o pagamento pelo controle.

Com relação ao momento da oferta quando, eventualmente, ocorrer um lapso temporal entre a contratação da aquisição e o pagamento efetivo, a CVM já manifestou seu entendimento de que oferta pública deverá ser realizada no momento da contratação. ${ }^{76}$

Por fim, no que tange as alienações de controle indireto, aquela que ocorre quando há a transferência de controle de sociedade controladora de companhia aberta, impende mencionar a dificuldade de cálculo do preço a ser pago em razão do tag along. Nestes casos, é necessária a elaboração de uma avaliação relativa à participação da companhia controlada no valor total pago pela aquisição de controle da controladora, conforme o disposto na Instrução CVM n. 361. ${ }^{77}$

\footnotetext{
${ }^{76}$ Conforme Parecer CVM/SJU n. 63/83.

77 Instrução CVM 361, artigo 19, parágrafo sexto: "No caso de alienação indireta do controle acionário, o ofertante deverá submeter à CVM, juntamente com o pedido de registro, a demonstração justificada da forma de cálculo do preço devido por força do artigo 254-A da LSA, correspondente à alienação do controle da companhia objeto."
} 


\section{CAPÍTULO 3 - O DIREITO DE VENDA CONJUNTA NA ORDEM ECONÔMICA}

As discussões acerca do tag along não se limitam ao campo jurídico. No econômico são igualmente intensas. Por se tratar de uma regra econômica, acarretando diversos efeitos às relações entre os agentes econômicos, o tag along divide a opinião dos autores quanto à sua eficiência.

Antes de nos filiar a uma das correntes, é preciso compreender a origem do movimento que deu origem ao tag along, para, em seguida, avaliar quais são seus efeitos, os seus custos e benefícios, e concluir se o tratamento conferido, pelo artigo 254-A, às alienações de controle produz um resultado eficiente para o mercado.

\subsection{Noções Gerais}

No princípio do capitalismo, a produção organizava-se de modo simples, individualmente ou em pequenos núcleos familiares. Com a evolução do capitalismo, o modo de produção passou a exigir investimentos cada vez mais altos. $O$ auge desse processo culminou na Revolução Industrial, na Inglaterra, em meados do século XVIII, que resultou numa profunda mudança no modo de produção, influenciado, principalmente, pelas idéias econômicas liberais predominantes à época.

Nesse contexto, o empresário individual ou familiar não era mais capaz de financiar integralmente a produção, vendo-se obrigado a captar recursos junto a terceiros. Curiosamente, o primeiro a reconhecer esse fenômeno foi KARL MARX:

\footnotetext{
"A produção capitalista chegou a um ponto em que o trabalho de direção, completamente separado da propriedade do capital, é por todos admitido, de tal
} 
arte que doravante o capitalista não tem mais necessidade de exercer pessoalmente esta função. Um maestro não precisa de modo algum ser proprietário dos instrumentos da orquestra que dirige, nem lhe compete tratar do salário dos seus músicos." 78

Os professores ALFREDO LAMY FILHO e JOSÉ LUIZ BULHÕES PEDREIRA, ao se referirem a este período, relatam que "à medida que o processo de desenvolvimento econômico mudava a escala da empresa e a obrigava a crescer, para sobreviver, capitais sempre maiores precisavam ser mobilizados e o antigo 'dono' - o empresário individual ou familiar - viuse constrangido a abrir a sociedade, admitir novos sócios, quaisquer que fossem as conseqüências (inclusive a perda do controle) porque seriam elas sempre melhores que a sanção da ineficiência, ou da incapacidade, que era a morte, ou seja, a falência". ${ }^{79}$

Em cima desta realidade, BERLE e MEANS desenvolveram sua clássica obra The Modern Corporation and Private Property, conhecida como a mais importante sistematização da teoria da separação entre propriedade e controle nas sociedades. De acordo com a sua teoria, a "dissolução do átomo da propriedade destrói o fundamento da ordem econômica dos últimos três séculos" devido à "dissolução do velho átomo da propriedade em suas partes componentes, o controle e os benefícios da propriedade". ${ }^{80}$

Em síntese, BERLE e MEANS defendiam que o proprietário contemporâneo teria, na verdade, um símbolo da propriedade, a ação, enquanto que os poderes e responsabilidades estariam nas mãos dos administradores. Os acionistas seriam meros agentes passivos, porquanto a propriedade ativa (comando efetivo dos rumos da sociedade) estaria nas mãos dos administradores.

\footnotetext{
${ }^{78}$ Apud COMPARATO, Fábio Konder, Aspectos Jurídicos da Macro-Empresa, Op. cit., p. 72.

${ }^{79}$ Op. cit. p. 145.

${ }^{80}$ Apud EIZIRIK, Nelson, Questões de direito societário e mercado de capitais, Rio de Janeiro, Ed. Forense, 1987, p. 5.
} 
Essa tese, embora criticada por diversos autores, ${ }^{81}$ foi importante por demonstrar a existência de um processo de "atenuação" dos direitos da propriedade privada, passando os atuais proprietários (ao menos os minoritários) a uma situação cada vez mais passiva, característica dos investidores e não mais dos sócios, e de uma tendência ao enfraquecimento gradual da figura do empresário familiar clássico, substituído por uma tecnocracia gerencial. ${ }^{82}$

Com isso, surgem as chamadas relações de agência, que, de acordo com MICHAEL C. JENSEN e WILLIAM H. MECKLING, são aquelas que se estabelecem mediante um contrato pelo qual uma ou mais pessoas (os principais) incumbem outra pessoa (o agente) de executar algum serviço que envolva a delegação de certo poder de decisão. ${ }^{83}$

A relação de agência pode estabelecer-se entre diversos tipos de principal e agente. Quando uma companhia tem seu capital pulverizado no mercado, seu controle geralmente é exercido pelos administradores, de modo que as relações de agência se dão entre estes e acionistas (tipo de relação predominante nos Estados Unidos e na Inglaterra). Já em companhias de controle concentrado nas mãos de um acionista controlador, as relações de agência se dão entre este e os acionistas minoritários (comum em países da Europa Continental e no Brasil).

\footnotetext{
${ }^{81}$ Diversos autores contestaram a tese de Berle e Means por não aceitarem a completa cisão, na macroempresa, do poder de controle e do direito de propriedade, desaparecendo, por conseguinte, a propriedade privada nessas sociedades. Karl Renner, p. ex., defende que houve a dissociação entre a propriedade econômica e a definição jurídica da propriedade, e não o surgimento de uma nova forma de organização econômica com o desaparecimento da propriedade privada. Para os economistas neoclássicos, a dispersão acionária seria basicamente um arranjo contratual, por meio do qual os acionistas delegam aos administradores determinadas funções diretivas da sociedade. ${ }^{82}$ EIZIRIK, Nelson, Ibid., p. 18.

${ }^{83}$ Theory of the Firm: Managerial Behavior, Agency Costs and Ownership Structure, Journal of Financial Economics, 1976, v. 3, n. 4, p. 6. Disponível em: <http://papers.ssrn.com/sol3/papers.cfm?abstract_id=94043>. Acesso em 5 de fevereiro de 2009.
} 
A princípio, essa delegação pretende buscar eficiência, visto que o principal não dispõe de experiência, tempo, competência, ou capacitação e, por isso, confere ao agente poderes para gerenciar os recursos e a execução das atividades. Por outro lado, "se ambas as partes do relacionamento são maximizadores de utilidade, existe boa razão para acreditar que o agente não agirá sempre pelos melhores interesses do principal", ${ }^{84}$ o que gerará os conflitos de agência.

Com o objetivo de limitar as divergências entre principal e agente, o principal geralmente cria incentivos para os agentes e supervisiona suas atividades. Também é comum o principal exigir garantias do agente para coibir decisões prejudiciais aos seus interesses (bonding costs). Essa equação entre os custos de supervisão pelo principal, custos das garantias prestadas pelos agentes, e as perdas residuais resulta nos conhecidos custos de agência. ${ }^{85}$

Com efeito, o reconhecimento desse novo panorama nas sociedades anônimas mudou o foco econômico e jurídico daqueles que detinham os meios de produção para aqueles que o controlam. Conseqüentemente, a legislação de diversos países passou a tratar de questões ligadas à regulação da conduta dos administradores, à necessidade de identificação e atribuição de responsabilidades sociais aos controladores, a medidas de proteção aos investidores e à criação de um sistema amplo de publicidade (disclosure).

As discussões em torno dos conflitos de agência tomaram mais vigor em razão de diversos escândalos e, principalmente, com o surgimento, nos anos 90, do movimento denominado Governança Corporativa, segundo o qual "aqueles que efetivamente conduzem os negócios da companhia devem visar a maximização de valor para os acionistas, de modo que a

\footnotetext{
84 "If both parties to the relationship are utility maximizers, there is good reason to believe that the agent will not always act in the best interests of the principal.” (Ibid., p. 5). Tradução livre.

${ }^{85}$ Ibid., p. 6.
} 
sociedade consiga atrair capital 'paciente', de longo prazo e a um custo baixo e possa estar em constante crescimento, atendendo aos interesses de diferentes grupos". 86 Para LA PORTA et. al., a Governança Corporativa constitui um conjunto de ferramentas destinadas a evitar a expropriação dos acionistas minoritários pelos acionistas controladores e/ou dos acionistas pelos administradores. ${ }^{87}$

Essas expropriações se traduziriam em vantagens obtidas pelos controladores em benefício próprio e em prejuízo dos (demais) acionistas, sejam por meio de salários superiores aos de mercado, uso de bens da sociedade para fins particulares, preços de transferência, benefícios indiretos, operações com partes relacionadas e em condições desfavoráveis para a sociedade, insider trading, dentre outros. Regras garantidoras de proteção do investidor seriam, portanto, importantes para evitar essa apropriação indevida por parte de administradores e controladores.

Ademais, tais regras são relevantes para o desenvolvimento do mercado de capitais, pois criam um ciclo contínuo de incentivos à atividade empresarial e ao direcionamento da poupança dos investidores: uma maior proteção aos investidores os incentivariam a financiar as companhias, as quais, por sua vez, teriam mais incentivos para emitir novos valores mobiliários em virtude da maior disposição dos investidores em pagarem mais por eles, e assim por diante.

Por estas razões, diversos países passaram a incorporar regras protetoras, dentre elas, o tag along.

\footnotetext{
${ }^{86}$ ANDREZO, Andrea Fernandes, op. cit., p. 160.

${ }^{87}$ LA PORTA, Rafael; SILANES, Florêncio Lopez-de; SHLIEIFER, Andrei; VISHNY, Robert W., Investor Protection: Origins, Consequences, Reform, p.1. Disponível em: < http://papers.ssrn.com/sol3/papers.cfm?abstract_id=227587>. Acesso em 28 de maio de 2009.
} 
O mercado de capitais britânico foi o primeiro a adotar o tag along, no final dos anos $60,{ }^{88}$ inspirando outros países europeus a adotarem essa regra em seu ordenamento jurídico. Em abril de 2004, com a aprovação do European Takeover Directive 2004/25/EC, a legislação de todos os países membros da União Européia tiveram de incorporá-lo.

Impende notar que, embora o modelo europeu se assemelhe ao modelo brasileiro, ele tem algumas peculiaridades. A primeira delas referese à caracterização do controle, que é presumido, i.e., quando uma pessoa (natural ou jurídica) detém um determinado número percentual de direito a voto (percentual este que deve ser diretamente proporcional ao nível de concentração do capital) é considerada controlador. A outra diferença diz respeito à incidência da obrigação de realizar oferta pública. Pelas regras da União Européia, basta que um acionista alcance o percentual definidor do controle, para que nasça a obrigação de realizar oferta pública. Isto quer dizer que as aquisições originárias também ensejarão esta obrigação, diferente do caso brasileiro, em que a obrigação de oferta pública se restringe às aquisições derivadas.

A despeito da popularidade do tag along no Velho Continente, os Estados Unidos adotam outro mecanismo nos casos de alienação de controle. As cortes americanas consolidaram o entendimento de que os controladores são livres para alienar e negociar o seu bloco de ações, desde que não pratiquem atos fraudulentos e dentro dos princípios da boa-fé. ${ }^{89}$

No Brasil, o exercício do poder de controle começou a integrar os debates jurídicos apenas no final dos anos $50 .^{90}$ Inicialmente, esse

\footnotetext{
${ }^{88}$ A obrigação de realizar oferta pública quando da aquisição de controle de uma companhia está prevista no City Code on Takeover and Mergers, editado por uma associação de instituições denominada Panel on Takeovers and Mergers.

${ }^{89}$ Zetlin v. Hanson Holdings Inc.. 48 NY 2d 684, 421, NYS 2d. 877, 397 N.E. 2d. 387. Ver também Barnes v. Brown, 80 NY 527; Levy v. American Beverage.

${ }^{90} \mathrm{O}$ Decreto-lei n. $2.627 / 40$ não fazia qualquer previsão relacionada ao poder de controle.
} 
movimento se refletiu em algumas medidas legislativas ${ }^{91}$ que incentivavam a dispersão das ações entre o público, pois, aparentemente, caracterizaria uma etapa superior do capitalismo.

A partir da década de 70 surgem estudos mais relevantes sobre a necessidade de uma reforma na lei de sociedades anônimas a fim de equacionar os interesses divergentes. ${ }^{92}$

A percepção da existência desses interesses contrários nas sociedades anônimas brasileiras leva muitos autores a defenderem a necessidade de se conferir um tratamento especial a operações que envolvessem blocos de controle, com o objetivo de proteger minoritários, principalmente em virtude de certas alienações prejudiciais aos minoritários. ${ }^{93}$

Diante desse panorama, há autores que citam a proteção dos investidores como sendo o principal objetivo da regulação econômica. ${ }^{94} \mathrm{~A}$ forma como essa proteção é tratada, em alguns textos, pode transmitir a idéia de que quanto mais proteção, mais eficiente será o mercado. Todavia, é preciso ter cuidado com interpretações como esta, afinal, se esta proteção for concedida indiscriminadamente, pode provocar efeitos nocivos ao mercado e aos próprios minoritários.

\footnotetext{
${ }^{91}$ Entre essas medidas, cite-se o Decreto 54.105/64, que criou o Fundo de Democratização do Capital das Empresas - FUNDECE, destinado a incentivas o complemento de capital de giro às empresas industriais, prevendo que empresas que abrissem seu capital poderiam saldar seus débitos para com o fundo através de oferta das ações à subscrição pública. Outro exemplo é o Programa de Ação Econômica do Governo - PAEG, divulgado em 1964, que trouxe como conseqüência a edição da Lei n. 4.506/64 que introduziu o conceito de sociedade anônima de capital aberto.

92 Cita-se, a título de exemplo, as obras clássicas de Fábio Konder Comparato, Aspectos Jurídicos da Macroempresa, de 1970, e de Alfredo Lamy Filho, A Reforma da Lei das Sociedades Anônimas, de 1972.

${ }^{93}$ Os exemplos mais citados pelos autores são o caso da venda do controle do Banco da Bahia (ao Bradesco), em 1973 e o caso da Santa Casa de Misericórdia que foi prejudicada pelos acionistas controladores da instituição financeira de que eram minoritários que abusaram de sua posição para adquirir suas ações, revendendo-as, quando da alienação do controle detido por ele, a preço muito superior ao pago.

${ }^{94}$ EIZIRIK, Nelson, Mercado de Capitais - Regime Jurídico, $2^{\mathrm{a}}$ Ed., Rio de Janeiro, 2008, p. 18.
} 
É fundamental, portanto, que ela esteja alinhada aos seus objetivos econômicos e, com isso, sempre se obtenha o máximo de benefícios com o mínimo de custos. O objetivo da regulação não é garantir proteção, mas sim criar um ambiente institucional que incentive investidores a direcionarem suas poupanças para este mercado e as sociedades a emitirem publicamente seus valores mobiliários. ${ }^{95}$

\subsection{Efeitos Econômicos do Direito de Venda Conjunta da LSA}

A obrigação consubstanciada no artigo 254-A, embora exija a oferta pública para aquisição de ações dos minoritários por, no mínimo, 80\% do preço pago aos controladores, e não mais pelo preço integral, ainda representa um considerável ônus às alienações de controle.

No estudo da eficiência deste instituto, torna-se uma questão central a análise da natureza do ágio atribuído ao controle, bem como da forma pela qual este instituto impacta nas relações de mercado, avaliando os custos e benefícios envolvidos e se é possível se verificar, no longo prazo, o direcionamento para uma alocação eficiente de recursos.

\subsubsection{Benefícios e Custos Privados do Controle}

Grande parte dos trabalhos que analisam o tag along sob uma perspectiva econômica menciona a doutrina do private benefits of control. Em linhas gerais, pode-se afirmar que os benefícios privados do controle

\footnotetext{
${ }^{95}$ Em consonância com este entendimento, dispõe a exposição de motivos da LSA da seguinte forma:

“4. Projeto visa basicamente a criar a estrutura jurídica necessária ao fortalecimento do mercado de capitais de risco no País, imprescindível à sobrevivência da empresa privada na fase atual da economia brasileira. A mobilização da poupança popular e o seu encaminhamento voluntário para o setor empresarial exigem, contudo, o estabelecimento de uma sistemática que assegure ao acionista minoritário o respeito a regras definidas e eqüitativas, as quais, sem imobilizar o empresário em suas iniciativas, ofereçam atrativos suficientes de segurança e rentabilidade.." (grifou-se)
} 
(ou benefícios inerentes ao controle) compreenderiam todas as vantagens que o controlador pode extrair exclusivamente em função de sua posição.

\section{MICHAEL J. BARCLAY e CLIFFORD G. HOLDERNESS foram} os primeiros a estudar as conseqüências dos benefícios privados às relações de mercado. A partir da análise dos preços fixados em diversas operações de alienação de controle, eles concluíram que, se todos os acionistas usufruem dos benefícios sociais na proporção de sua participação no capital social (não existindo benefícios privados), o valor fixado pelo bloco de controle corresponde ao valor de mercado daquelas ações.

Diferentemente, se os controladores utilizam seu poder de voto para garantir benefícios privados (positivos), o valor fixado corresponderia ao valor de mercado adicionado de um prêmio correspondente ao valor descontado dos benefícios privados (líquidos) futuros. Por outro lado, se os novos controladores assumem os custos privados (quando os benefícios privados são negativos), o preço seria resultado do valor correspondente a esse custo diminuído do valor de mercado.

Ao longo do seu estudo, porém, BARCLAY e HOLDERNESS verificaram que, na maioria dos casos de alienação de controle, o valor fixado ao bloco de controle é substancialmente superior ao valor de mercado (em média 16\% superior), o que lhes permitiu concluir que, na maior parte das companhias, os benefícios privados do controle são positivos. $^{96}$

Outro trabalho interessante é o desenvolvido por ALEXANDER DICK e LUIGI ZINGALES. Os autores elaboraram um estudo empírico

\footnotetext{
${ }^{96}$ Private Benefits from Control of Public Corporations, 1989. Apud SEPE, Simone, Private Sale of Corporate Control: Why the European Mandatory Bid Rule Is Inefficient. Disponível em: <http://papers.ssrn.com/sol3/papers.cfm?abstract_id=1086321>. Acesso em 1 de fevereiro de 2009.
} 
sobre o valor do prêmio nas alienações de controle de 39 países, dentre eles o Brasil, partindo da premissa de que o prêmio resulta da diferença entre o valor pago por cada ação integrante do bloco de controle e o valor de mercado das ações.

A média do valor do prêmio em relação ao valor das ações no mercado foi de $14 \%$, entretanto, a variação de país para país foi significante. Por exemplo, na Itália verificou-se uma média de 37\%, no México de 34\%, na Alemanha de 10\%, na Suíça de 6\%, e nos Estados Unidos e na Inglaterra de $1 \%$. Um resultado que chama atenção é o do Brasil, em que se verificou uma média de $65 \%$, a mais alta dentre os países analisados.

Os autores concluíram que os valores dos prêmios estão associados à extração de benefícios privados, sendo que nos países em que a extração de benefícios privados é alta, o mercado de capitais é menos desenvolvido e a proteção aos minoritários é insuficiente. ${ }^{97 / 98}$

De acordo com RONALD GILSON e JEFFREY GORDON os benefícios privados do controle podem ser extraídos de 3 formas: (i) na condução dos negócios sociais (e.g., por meio de contratações com partes relacionadas, ou tomando decisões baseadas no seu exclusivo interesse), (ii) pela alienação do controle da companhia por um prêmio que reflete o valor capitalizado da extração de benefícios privados disponíveis na condução dos negócios; e (iii) em operações que obrigam os minoritários a alienarem

\footnotetext{
${ }^{97}$ Private Benefits of Control: An International Comparison. Disponível em: <http://papers.ssrn.com/sol3/papers.cfm?abstract_id=296107>. Acesso em 2 de março de 2009. ${ }_{98}$ Outros trabalhos chegam a conclusões interessantes a esse respeito: LA PORTA et. al., op. cit.; idem, Legal Determinants of External Finance, disponível em: <http://www.nber.org/papers/w5879.pdf?new_window=1>, acesso em 2 de junho de 2009; e COFFEE JR., John C., Do norms matter?: A Cross-Country Examination of the Benefits of Control, disponível em: <http://papers.ssrn.com/sol3/papers.cfm?abstract_id=257613>. Acesso em 29 de maio de 2009.
} 
sua participação por um preço que reflita o desconto dos benefícios privados disponíveis na condução dos negócios (freezing out minority). ${ }^{99}$

É mister ressaltar que nem todo benefício privado significa uma apropriação de valor do minoritário. Há, na verdade, os dois tipos, aqueles que extraem e aqueles que não extraem valor dos minoritários. Os primeiros compreendem benefícios que correspondem a um prejuízo dos demais acionistas (e.g. usurpação de uma oportunidade da companhia, ou negociação com uma parte interessada em condições desfavoráveis). Os últimos são aqueles que apenas criam valor para o controlador sem extrair valor algum de outrem (e.g., reputação do controlador, ou a utilização de uma oportunidade descartada pela companhia, ou a negociação com parte relacionada em justas condições), resultando sempre numa situação econômica eficiente no sentido de Paretto. ${ }^{100}$

A partir destas considerações, alguns autores alegam que, pelo fato de as ações integrantes do bloco de controle valerem mais do que as ações minoritárias, por refletirem a expectativa de extração de benefícios privados, este spread induziria os controladores a tomarem decisões exclusivamente no seu interesse (isto é, extraindo mais benefícios privados), pois, assim, o controlador maximizaria o valor do prêmio de controle. Diante disto, a obrigação de dividir o valor do prêmio com os minoritários, decorrente do tag along, seria eficiente na medida em que o incentivo dos controladores para extrair benefícios privados se reduziria. ${ }^{101}$

\footnotetext{
${ }^{99}$ Controlling Controlling Shareholders. Disponível em: $<$ http://papers.ssrn.com/abstract=417181>. Acesso em 5 de fevereiro de 2009.

${ }^{100}$ Eficiência ou Ótimo de Paretto é aquela situação em que alguém melhora de condição sem haja uma piora na situação de outrem. Por serem restritas as situações em que este conceito é aplicável, o conceito de eficiência de Kaldor-Hicks costuma ser mais utilizado.

101 TESTA, Pedro, Op. cit.
} 
Veremos adiante, porém, que a lógica econômica é complexa, sendo fundamental analisar os seus efeitos como um todo, para que se examine a adequação deste mecanismo em coibir tais extrações pelos controladores.

Para que uma companhia seja bem sucedida, ela deve ser bem administrada, maximizando, no longo prazo, a geração de lucros para os seus acionistas. Mas qual estrutura social adotar para alcançar estes objetivos é uma questão complicada. Todavia, é praticamente um consenso que deixar a administração à mercê dos administradores não costuma ser o melhor caminho, já que, em geral, seus objetivos não estão exatamente alinhados com os interesses dos acionistas.

Nessas circunstâncias, a figura do acionista controlador pode funcionar como uma das soluções mais adequadas por diversas razões. Em primeiro lugar, o controlador é quem tem os maiores incentivos para buscar o bom desempenho da companhia, pois, devido à sua participação elevada no capital social, seu risco será superior ao dos demais acionistas. Para tanto, o controlador exercerá seu poder de controle para supervisionar e cobrar metas dos administradores. Além disso, tendo em vista o caráter permanente do seu investimento, o controlador poderá implementar estratégias para retornos de longo prazo.

Nesse sentido, há, inclusive, estudos que indicam a existência de uma correlação positiva entre a concentração de capital e o desempenho das companhias. A título de exemplo, ANDERSON e REEB, ao avaliar as 500 companhias que integram o índice $\mathrm{S} \& \mathrm{P} 500,{ }^{102}$ chegaram, dentre outras, às seguintes conclusões: (i) que em um terço delas, as famílias fundadoras detém uma participação substancial, e nestas companhias, controlam cerca de $20 \%$ dos órgãos sociais; (ii) que o desempenho destas companhias era

\footnotetext{
${ }^{102}$ S\&P 500 é um índice composto pelos quinhentos ativos (ações) mais importante para o mercado, qualificados devido ao seu tamanho de mercado, sua liquidez e sua representação de grupo industrial.
} 
superior ao das demais; (iii) que não há indícios de que o controle exercido por um grupo familiar leva à expropriação dos minoritários; e (iv) que, de forma geral, os minoritários se beneficiam da presença de famílias fundadoras da companhia. ${ }^{103}$

JEREMY EDWARDS e ALFONS WEICHENRIEDER, por sua vez, com base nos dados de um grupo de companhias alemãs, verificaram que os efeitos causados pela atuação do controlador são mais benéficos do que prejudiciais. ${ }^{104}$

O exercício do poder de controle, assim, reduz substancialmente os custos de agência próprios de estruturas de controle disperso, alcançado, no entanto, mediante um alto custo para o controlador (private costs of control), resultante da soma do custo para supervisionar a administração, dos custos de aplicar um investimento alto num único empreendimento, do custo de ter a liquidez de seu bloco de ações reduzida, dos custos de estar sujeito a responsabilidades próprias do controlador, dentre outros. Numa eventual alienação de controle, o controlador ainda poderá atuar positivamente para a operação, seja negociando o melhor preço, seja oferecendo garantias ao adquirente relativas à operação, que, aliás, se somarão aos seus outros custos.

RICHARD POSNER, discutindo a separação do controle e da propriedade, defende que se trata de um fenômeno eficiente, visto que o

\footnotetext{
${ }^{103}$ ANDERSON, Ronald C.; MANSI, Satar A.; REEB, David M., Founding Family Ownership and the Agency Cost of Debt, disponível em: <http://papers.ssrn.com/sol3/papers.cfm?abstract_id=303864>; ANDERSON, Ronald C.; REEB, David M., Founding-Family Ownership, Corporate Diversification, and Firm Leverage, disponível em: <http://papers.ssrn.com/sol3/papers.cfm?abstract_id=462541>, Who monitors the family?, disponível em: <http://papers.ssrn.com/sol3/papers.cfm?abstract_id=369620>, 2003b, Founding Family Ownership and Firm Performance: Evidence from the S\&P 500, disponível em: <http://papers.ssrn.com/sol3/papers.cfm?abstract_id=365260>, e Board Composition: Balancing Family Influence in S\&P 500 Firms, disponível em: <http://papers.ssrn.com/sol3/papers.cfm?abstract_id=590305>. Acessos em 2 de junho de 2009.
} 
custo de oportunidade de se atuar ativamente na administração dos negócios sociais se revela excessivo para a maioria dos acionistas. ${ }^{105}$ Em outras palavras, o fenômeno da separação da propriedade permitiu a arrecadação de elevados investimentos, sendo que os custos do exercício do poder de controle seriam incorridos apenas por aqueles que o exercessem.

Os benefícios e os custos privados do controle representam, na verdade, dois lados de uma mesma moeda, pois se originam do fato de o controlador ter o poder de decidir e de que tais decisões podem ser positivas ou negativas do ponto de vista dos demais acionistas.

Em vista disso, é preciso estabelecer mecanismos que reduzam a extração de benefícios privados ineficientes, sem, contudo, sacrificar as vantagens de se ter o poder nas mãos do controlador, mediante incentivos para que os agentes busquem a valorização das ações no longo prazo, e regras que os coíbam de praticar atos que reduzam seu valor ou desviem-no para si. $^{106}$

Importante destacar que tais incentivos desempenham um relevante papel para o crescimento das companhias. Ao promover a competição pelo controle, estes incentivos tendem a elevar o nível da eficiência dos acionistas controladores.

O prêmio de controle, considerado um benefício privado, ${ }^{107}$ reflete a capitalização da expectativa de extração dos benefícios privados na condução dos negócios da companhia. Portanto, numa alienação de

${ }^{104}$ Ownership Concentration And Share Valuation: Evidence From Germany, Working Paper N. 193, 1999. Disponível em: <http://papers.ssrn.com/sol3/papers.cfm?abstract_id=272627>. Acesso em 27 de maio de 2009.

${ }^{105}$ Economic Analysis of Law, Editorial Advisory Board, 1992, p. 414.

${ }^{106}$ KARL, Hoffstein, One Size Does Not Fit All: Corporate Governance for 'Controlled Companies', p. 19. Disponível em: 〈http://papers.ssrn.com/sol3/papers.cfm?abstract_id=802705>. Acesso em 5 de abril de 2009.

${ }^{107}$ GILSON, Ronald; e GORDON, Jeffrey, op. cit. 
controle, um controlador que exproprie benefícios privados, ainda, se apropriará do valor capitalizado de expropriações futuras. Porém, se não há a possibilidade de extrair benefícios, o prêmio representaria apenas a expectativa da valorização da companhia sob a direção do novo controlador.

Ora, assim parece muito claro que o prêmio de controle, em si, não dissipa valor algum da companhia ou do minoritário, mas apenas valoriza a situação do controlador, configurando uma situação Paretto-ótima. Diante disso, constata-se que a sua existência pode funcionar como um eficiente incentivo para que se garanta a presença positiva do controlador, que será contrabalanceado com os ônus de sua posição. KARL HOFSTETTER também é desta opinião:

\begin{abstract}
"Principles of non-discrimination and equal treatment generally prevent higher payments to a controlling shareholder unless he owns some type of preferred shares. Direct payments for external costs of control are not allowed either across jurisdictions and would be considered illegal self-dealing. (...) Control premiums, often treated skeptically among legal academics, therefore, appear as a potentially efficient (deferred) compensation device for the external costs of control of controlling shareholders." 108
\end{abstract}

WALDÍRIO BULGARELLI, nesta mesma linha, defende que:

\begin{abstract}
"A alienação do controle tem sido alvo de grandes discussões, entre nós, sobretudo pela disparidade que acarreta entre o preço pago às ações de controle e às dos não-controladores. (...)

Aos reclamos de que tal situação é injusta para com os não controladores, invocase o fato de que o ágio que o controlador obtém quando da venda do controle justifica-se porque constitui o pagamento dos seus esforços em dirigir a companhia, e que os rendeiros e especuladores que se mantêm indiferentes às
\end{abstract}

\footnotetext{
108 Op. cit., p. 33. ("Princípios de não-discriminação e de tratamento igualitário geralmente impedem o pagamento de valores mais altos ao acionista controlador, a não ser que este detenha alguma espécie de ação preferencial. Pagamentos diretos por custos externos do controle também não são permitidos e seriam consideradas negociações ilícitas em interesse próprio (...). Prêmios de controle, frequientemente tratados com ceticismo por acadêmicos, portanto, parecem um mecanismo potencialmente eficiente de compensação (diferida) ao acionista controlador pelos custos externos de controle." Tradução Livre)
} 
vicissitudes da vida societária não podem, por isso, reivindicar igualdade de tratamento." 109

Já com relação àqueles benefícios privados que resultam em uma apropriação de valor dos minoritários na condução dos negócios da companhia, a situação é diferente. Estes sim devem ser impedidos pelo sistema legal, mediante a fixação de standards de conduta dos agentes (e.g. vedação de práticas de negociação com informações privilegiadas, ou com partes relacionadas em condições abaixo do mercado, ou quaisquer práticas fraudulentas ou abusivas pelos administradores ou acionistas controladores) e normas relativas à transparência (disclosure), dentre outras, ${ }^{110}$ combinadas com mecanismos eficazes de fiscalização e coerção (enforcement). ${ }^{111}$

Ressalte-se que não se trata, aqui, de defender que as companhias com capital concentrado são mais eficientes. Companhias com estrutura de controle concentrado, assim como as de controle pulverizado, têm seus prós e contras. Trata-se, porém, de destacar a importância de se criar um ambiente institucional em que ambas as estruturas possam competir em condições equivalentes.

Outros autores em favor do artigo 254-A da LSA sustentam, ainda, que a obrigação de realizar oferta pública aos minoritários seria benéfica às companhias por “desencorajar o comprador 'com espírito aproveitador' sem desencorajar o comprador com 'espírito empreendedor', pois este último, se vislumbrar a possibilidade de aumentar o valor da companhia com técnicas administrativas mais eficientes, não deverá deixar de adquirir as ações

\footnotetext{
${ }^{109}$ Regime Jurídico da Proteção às Minorias nas S/A, Rio de Janeiro, Renovar, 1998, p. 157-8.

${ }^{110}$ Para Posner: "What is necessary in the interests of the shareholders is not participatory shareholder democracy but machinery for discouraging management from deflecting too much of the firm's net income from the shareholder to itself." (Op. cit., Economic Analysis of Law, p. 414). ${ }^{111}$ Nessa linha, Bernard Black sustenta ser condição para o desenvolvimento do mercado de capitais que a legislação e as instituições assegurem aos acionistas não controladores: (i) informações adequadas sobre o valor da companhia; e (ii) confiança de que não serão expropriados pelos administradores e/ou controladores em operações com parte relacionada. (Streghening Brazil's Security Markets, Revista de Direito Mercantil, vol. 120, 2000, p. 41-55).
} 
minoritárias, pois elas também se valorizarão, posteriormente, com boa administração da companhia". Em cima disso, concluem que, no médio prazo, o tag along filtraria as operações de transferência de controle para controladores "com espírito de aproveitador" (looters) - aqueles que visam apenas extrair benefícios privados do controle -, selecionando apenas aquelas em que o comprador se propõe a realizar melhoras administrativas. ${ }^{112}$

Em função do alto custo que acarreta, o tag along, de fato, funcionará como um verdadeiro filtro. Porém, o tag along filtrará não apenas alienações de controle ineficientes (i.e., alienações para controladores “com espírito de aproveitador”), mas também as eficientes.

Numa alienação de controle, adquirente e alienante negociarão o valor devido pelo poder de controle de uma determinada companhia, sendo certo que esta operação terá grandes chances de se concretizar quando o adquirente oferecer um valor superior ao valor que o alienante calcula ser capaz de agregar àquela companhia.

O preço máximo a ser oferecido por um potencial adquirente corresponderá ao valor total das ações no mercado somado ao valor que ele calcula que será capaz de agregar à companhia. Em conformidade com esse raciocínio, FRANK EASTERBROOK e DANIEL FISCHEL, in verbis:

"Control transactions reflect substantial gains. Sale of control bloc of stock, for
example, allows the buyer to install his own management team, producing any
gains available from the new structure. Because such buyer believes to pay a
premium over the market price to acquire control. The premium will be some
percentage of the anticipated increase in value once the transfer of control is
effectuated. If there were no anticipated increase in value, it would be irrational
for the buyer to pay the premium. Self-interest thus assures us that changes of

${ }^{112}$ GORGA, Erica, Análise da Eficiência de Normas Societárias: Emissão de Preferenciais, Tag Along e Composição do Conselho Fiscal. p. 15-23. Disponível em: $<$ http://repositories.cdlib.org/cgi/viewcontent.cgi?article=1079\&context=bple>. Acesso em 5 maio de 2009. 
corporate control, like other voluntary exchanges, move assets to higher valued uses." 113

O controlador (alienante), por sua vez, aceitará a oferta quando considerar improvável que possa agregar mais valor às suas ações do que o valor oferecido pelo comprador, descontado o seu valor de mercado.

Ao se impor a obrigação de realizar oferta pública ao adquirente nos moldes do artigo 254-A da LSA, um interessado em adquirir o controle de uma companhia descontará do valor a ser oferecido o custo que estima a ser gasto com o tag along, o qual, todavia, nem sempre será vantajoso ao atual controlador.

Assim, em função do custo referente ao tag along, uma substancial parte de operações que ocorreriam nos termos acima será filtrada, por se tornarem excessivamente onerosas do ponto de vista financeiro, provocando um verdadeiro desequilíbrio do ponto considerado ótimo para alienante e adquirente.

Em vista disso, é possível que haja um interessado, mais eficiente, em adquirir o controle de uma companhia, cuja oferta não corresponda à avaliação do controlador, e que não considere vantajoso elevar o valor da oferta feita pelo controle. Nessa linha, FRANK EASTERBROOK e DANIEL FISCHEL sustentam:

"Sales of controlling blocs of shares provide a good example of transactions in which the movement of control is beneficial. The sale of control may lead to new offer, new plans, and new working arrangements with other firms that reduce

\footnotetext{
113 The Economic Structure of Corporate Law, First Harvard University Press, 1996, p.112. ("Transações de controle refletem ganhos substanciais. A venda de ações do bloco de controle, por exemplo, permite que o adquirente instale sua própria equipe de administração, produzindo todo lucro disponível na nova estrutura, pois este adquirente acredita que paga um prêmio acima do valor de mercado para adquirir o controle. O prêmio vai ser uma porcentagem do aumento de valor que se espera após a transferência de controle, a qual, caso não existisse, tornaria irracional o pagamento do prêmio de controle pelo adquirente. $\mathrm{O}$ interesse próprio, conseqüentemente, assegura que a mudança de controle societário, como qualquer outra troca voluntária, movimente ativos para a utilização mais valorizada.” Tradução Livre).
} 
agency costs and create gains from business relationship. The premium price received by the seller of the control bloc amounts to an unequal distribution of the gains. Sales at premium are lawful, and the controlling shareholder generally has no duty to spread the bounty. For the reasons we have discussed, this unequal distribution may cut the cost to purchasers of control, increasing the number of beneficial control transfers by the incentive for inefficient controllers to relinquish their positions." 114

Nessas condições, uma alienação de controle só será vantajosa para o adquirente e para o alienante quando o adquirente for eficiente a tal ponto que o sobrepreço devido aos minoritários seja compensado, restringindo esse movimento positivo de transferências do controle para controladores mais eficientes, o que será prejudicial tanto à companhia quanto aos próprios minoritários. SIMONE SEPE, ainda, acrescenta que:

"The equal-sharing rule can inflate the total purchase price beyond the buyer's reservation price and, thereby, prevent that shareholders may benefit from the increased value that their stock would have under the buyer's management. It follows that the MBR (mandatory bid rule) can be considered efficient only if the aggregate value of the inefficient transactions that it deters is higher than the aggregate value of the efficient sales of control that would occur in its absence." 115

\section{A esse respeito, RICHARD POSNER também manifesta opinião}

bastante interessante:

“(...) There would be another obstacle if proposals were adopted that would forbid a controlling shareholder, in selling his shares, to charge a premium for the control of the corporation that the sale bestows on the buyer. The underlying theory is that controlling shareholder has fiduciary obligations to the minority shareholders. The theory has merit in the special case (...) where there is a

\footnotetext{
${ }^{114}$ Ibid., p. 126. ("Vendas de blocos de controle acionário são um bom exemplo de transações onde o movimento do controle é benéfico. A venda do controle pode levar a uma nova produção, novos planos e novos projetos de trabalho com outras companhias que reduzem os custos de agência e criam ganhos dessas relações de negócio. O preço do prêmio recebido pelo alienante do bloco de controle leva a uma distribuição desigual dos lucros. Vendas com prêmio são lícitas, e o acionista controlado geralmente não tem o dever de distribuir o valor. Pelas razões já discutidas, esta distribuição desigual pode reduzir o custo para adquirentes do controle, aumentando o numero de transferências de controle benéficas pelo incentivo que os controladores ineficientes têm de desistir de sua posição." Tradução Livre)

${ }^{115}$ Op. cit., p. 28. ("A regra do tratamento igualitária pode inflacionar o preço total de aquisição para além do preço de reserva do adquirente, impedindo que os acionistas sejam beneficiados pelo acréscimo que valor que suas ações experimentariam sob a administração do comprador. Conseqüentemente, a OPA (oferta pública para aquisição de ações) só pode ser considerada eficiente se o valor agregado das transações ineficientes que ele impede for superior ao valor agregado das alienações eficientes de controle que ocorreriam em sua ausência.” Tradução Livre).
} 
conflict of interest between majority and minority shareholders. But in the usual takeover situation, the minority shareholders will be more harmed than benefited by a rule that, by reducing the controlling shareholder's incentive to sell control, retards the reallocation of the assets of the corporation to people who can use them more productively to the benefit of all of the shareholders.(...)

Antitakeover devices (...) are defended as promoting equality among shareholders, causing tender offerors to sweeten their offers, and correcting undervaluations by the market. These defenses are implausible (the last especially, in view of the efficient market thesis explored in the next chapter). Their major effect is to discourage tender offers, and some studies have shown that when tender offers are defeated the shareholders of the target corporation all of them - suffer losses." 116

A situação descrita acima se revela ainda mais crítica no caso de companhias deficitárias, em que a alteração do controle poderia ser fundamental para o seu saneamento ou, até mesmo, para a sua continuidade. $^{117}$

Além destas ineficiências, o argumento de que estes custos seriam compensados com os benefícios de se evitar as alienações para controladores “com espírito aproveitador”, igualmente não resiste.

Primeiro porque, como explicado acima, pressupõe-se que uma alienação de controle tende a ocorrer quando um agente (adquirente) espera lucrar mais do que o atual controlador. Ou seja, este agente desejará adquirir o controle em 2 hipóteses: (i) se se julgar mais eficiente, sendo

\footnotetext{
${ }^{116}$ Op. cit., Economic Analysis of Law, p. 414. (“(...) Ainda existiria outro obstáculo caso fossem adotadas propostas proibindo que o acionista controlador, quando vendesse suas ações, receber um prêmio pelo controle da sociedade atribuído ao comprador. A teoria prevalecente é que o acionista controlador tem obrigações fiduciárias com relação aos acionistas minoritários. A teoria tem mérito no caso específico (...) onde não há conflito de interesse entre acionista controlador e minoritários. Contudo, normalmente, nas alienações, os minoritários serão mais sacrificados que beneficiados por uma regra que reduza o incentivo de venda do controle da sociedade, por parte do controlador, obstruindo a reaolocação dos bens da companhia a pessoas que podem fazer um uso mais produtivo e promovendo mais benefício a todos os acionistas. Quaisquer mecanismos de takeover, são defendidos como promovendo igualdade entre os acionistas, fazendo com que compradores tonifiquem suas ofertas, e corrigindo sub-avaliações por parte do mercado. Estes argumentos são implausíveis (em especial o último, tendo em vista a tese de eficiência do mercado explorado adiante no próximo capitulo). Seu maior efeito é desencorajar ofertas eficientes, e alguns estudos têm mostrado que quando uma oferta eficiente é impedida, os acionistas, todos estes, da companhia alvo sofrem perdas.” Tradução Livre)

${ }^{117}$ SANTOS, J. A. Penalva, Direito dos Minoritários - Alienação de Controle de Companhias Abertas e os Direitos dos Minoritários. Análise do art. 254-A da Lei n. 6.404 de 1976. in LOBO,
} 
capaz de obter lucros mais elevados; ou (ii) se se considerar capaz de extrair mais benefícios privados. Com relação à segunda hipótese, contudo, se ambos, adquirente e alienante, atuam num mesmo ambiente institucional e sob o mesmo regime legal, é pouco provável que tantas alienações fossem motivadas exclusivamente por este fator a ponto de justificar a obrigação de realizar oferta pública. ${ }^{118}$ Esta assertiva, inclusive, se ajusta à conclusão de estudos que demonstram que, em países sem previsão legal da obrigação de realização de oferta pública, como nos Estados Unidos, as transferências de grandes blocos de ações, geralmente, geram uma considerável valorização das ações. ${ }^{119}$

E, em segundo lugar, considerando o elevado nível de extração de benefícios privados no Brasil - cuja média do valor do prêmio de controle atinge $65 \%$ do valor de mercado das ações -, o que, por si, já restringe as alienações de controle por requerer um alto investimento, a imposição da obrigação de oferta pública dificultará ainda mais a aquisição do controle das companhias por um controlador mais eficiente. ${ }^{120}$ Esta situação reforça a opinião manifestada acima, de que mais apropriado seria coibir direta e efetivamente a prática de condutas que extraem valor.

Outro fator negativo é a dificuldade de se mensurar com alto grau de certeza a aderência dos minoritários à oferta de compra de suas ações, o que acarreta duas situações desvantajosas: (i) o adquirente estará sujeito a, ao final da oferta, deter uma participação muito superior àquela desejada, o que também pode levá-lo a desistir da operação; e (ii) a dificuldade de se calcular o preço pelo controle, o que poderá ser prejudicial tanto ao

Jorge (Coordenador). Reforma da Lei das Sociedades Anônimas: inovações e questões controvertidas da Lei ${ }^{\circ}$ 10.303, de 31.10.2001. Rio de Janeiro: Forense, 2002, p. 495.

${ }^{118}$ Segundo Simone Sepe, "the size of DPB (dissipative private benefits) that a controlling blockholder is able to extract depends on the legal environment, the kind of industry, and the level of competition of the country where the target is chartered." (Op. cit., p. 39). 
alienante (por ter aceitado um valor inferior ao máximo possível) quanto ao adquirente (por despender mais do que pretendia), conforme o caso.

Com base nos fundamentos acima, chega-se a outra conseqüência para o mercado. Os acionistas de companhias fechadas que desejam buscar financiamentos para expansão dos negócios sociais têm a opção de buscálos via mercado. Entretanto, especialmente em países onde predominam as companhias cuja estrutura de capital é mais concentrada, como no Brasil, a obrigação de realizar oferta pública significará um substancial desincentivo para que novas sociedades recorram ao mercado de capitais, ${ }^{121}$ já que a redução da liquidez que o bloco de controle passará a ter em razão do tag along será considerada.

A concentração de capital também é uma distorção causada pela obrigação de realizar oferta pública. Na medida em que a referida obrigação onera as transferências de controle, uma oferta hostil para a aquisição de controle passa a ser uma alternativa. Diante disto, a referida obrigação poderá induzir os controladores a elevarem a sua participação a fim de evitar a "expropriação" do seu poder de controle. ${ }^{122}$ Esta situação é agravada pelo critério de controle adotado pela LSA para a definição de acionista controlador (controle de fato), visto que uma determinada participação social que torne o controle possível, mas que não seja majoritária, poderá vir a ser superada por meio de aquisições sucessivas de ações no mercado ou de uma oferta hostil. Inversamente, como salienta LUCIAN BEBCHUCK, a adoção de regras que reduzam a extração de

\footnotetext{
${ }^{119}$ A esse respeito, conferir BARCLAY, Michael J.; e HOLDERNESS Clifford G., The Law and Large-Block Trades, Journal of Law \& Economics, 1992, vol. 35, Issue 2, pages 265-94.

${ }^{120}$ Repita-se, já que o custo referente ao tag along restringe as situações ótimas para o adquirente e o alienante.

${ }^{121}$ BEBCHUCK, Lucian Arye, A Rent-Protection Theory of Corporate Ownership and Control, p. 33. Disponível em: <http://www.law.harvard.edu/faculty/bebchuk/pdfs/nber7203.99.pdf>. Acesso em 29 de maio de 2009.

${ }^{122}$ SEPE, Simone, op. cit., p. 44-6.
} 
benefícios privados na condução dos negócios pelos controladores, levaria a escolhas eficientes de estruturas de capital. ${ }^{123}$

Faz-se oportuno destacar outro interessante outro trabalho deste autor, que comparou a eficiência, em diversos aspectos, das operações de alienação de controle sob regimes legais que prevêem a obrigação de realizar oferta pública e sob o regime que deixa esta decisão nas mãos do mercado. Ao final do seu estudo, o autor concluiu que, ao se agregar todos os aspectos destas operações, as forças do mercado alcançam um resultado mais eficiente. ${ }^{124}$

Assim, observa-se que o tag along distorce os movimentos de alocação de recursos do mercado, ao constituir um desincentivo às alienações que agregam valor à companhia e ao financiamento das companhias via abertura de capital, fixando-os em níveis sub-ótimos, e por obstruir a adoção de estruturas ótimas de capital, inibindo o desenvolvimento econômico e a alocação eficiente dos recursos.

\subsubsection{Direito de Retirada}

Outro argumento utilizado para justificar a obrigação de realizar oferta pública fundamenta-se na idéia de que deve ser garantido o direito de saída do minoritário em justas condições, quando mudam as bases de controle da empresa. Ao decidir sobre investir numa companhia, o acionista levaria em consideração quem é seu controlador, ou seja, quem efetivamente conduz os negócios, existindo uma verdadeira relação intuitu personae. Ante uma mudança de controle, portanto, os minoritários deveriam ter direito de se retirar, caso não concordem em permanecer

\footnotetext{
${ }^{123}$ Op. cit., p. 31.

${ }^{124}$ Efficient and inefficient sales of corporate control, p. 24. Disponível em: <http://papers.ssrn.com/sol3/papers.cfm?abstract_id=520943>. Acesso em 2 de junho de 2009.
} 
associados ao novo controlador, ${ }^{125}$ sendo que a garantia deste direito reduziria o custo para a captação de recursos no mercado.

Este argumento baseia-se numa presunção equivocada de que alterações de controle, em geral, são prejudiciais aos demais acionistas, não sendo lógica a exigência de realização de oferta para compra das demais ações, salvo nos casos em que ficasse provado um efetivo prejuízo. ${ }^{126} \mathrm{O}$ referido argumento encontra-se, inclusive, em desacordo com os estudos que demonstram a valorização da companhia no período que sucede as alienações de controle. ${ }^{127}$

Ademais, se esta presunção estivesse realmente correta, qualquer forma de alteração de controle deveria ensejar a obrigação de realizar oferta pública, incluindo os casos de aquisição de controle originária e operações em geral que resultassem numa mudança de controle.

\subsubsection{Afinal, o direito de venda conjunta na forma do artigo 254-A da LSA é eficiente?}

Com base no exposto acima, conclui-se que o artigo 254-A da LSA falha no seu principal objetivo - proteger o minoritário em operações de alienação de controle - pois (i) não é o meio adequado para coibir a extração de benefícios privados do controle; e (ii) impede a concretização de diversas operações que agregariam valor à companhia.

O artigo 254-A seria eficiente na hipótese de se verificar, pelo menos, que (i) na ausência do tag along, haveria um número considerável de aquisições de controle oportunistas; (ii) o prejuízo causado aos

\footnotetext{
${ }^{125}$ EIZIRIK, Nelson, Mercado de Capitais - Regime Jurídico, op. cit., p. 588., e ANDREZO, Andréa, op. cit., p.173.

${ }^{126}$ SKOG, Rolf, Does Sweeden Need a Mandotory Bid Rule?, Amsterdam, SUERF Studies 2, 1997, disponível em 〈http://www.suerf.org/download/studies/study2.pdf〉, acesso em 5 de maio de 2009.
} 
minoritários seria superior ao ganho do controlador; e (iii) a obrigação de realizar oferta pública impediria operações ineficientes cujo valor agregado fosse superior ao valor agregado das operações eficientes igualmente inviabilizadas. Não há, contudo, qualquer evidência ou estudo que comprove que estas três hipóteses sejam verdadeiras. Longe disso. Há apenas manifestações baseadas em interpretações equivocadas dos dados estatísticos. $^{128}$

Se um dos principais objetivos do tag along é impedir a extração de benefícios privados prejudiciais à companhia e aos minoritários - que, em última análise, caracterizam condutas violadoras dos deveres fiduciários devidos pelos controladores e administradores -, mais eficiente e menos sacrificante para o mercado seria direcionar esforços diretos para impedir a prática de tais condutas. Desta forma, exigir que o controlador compartilhe o valor do prêmio de controle revela-se inadequado para atingir este fim. Este raciocínio, ainda, demonstra-se de acordo com as conclusões dos estudos mencionados acima que tratam da relação inversa entre a extração de benefícios privados e o nível de desenvolvimento da regulação do mercado. $^{129}$

\footnotetext{
${ }^{127}$ Estudo citado acima de Michael J. Barclay, e Clifford G. Holderness.

${ }^{128}$ Cite-se a este respeito matérias que associam o desempenho das companhias listadas no segmento do Novo Mercado ao tag along mais rígido previsto em suas regras. Esta interpretação é completamente infundada, pois há diversos outros fatores que influenciam no desempenho das companhias, além de as regras do Novo Mercado não preverem apenas o direito ao tag along, mas outras regras, que coíbem a extração dos investidores. Outra interpretação comum é a de que haveria uma relação direta entre a elevação do valor do prêmio de controle no período compreendido entre a extinção do artigo 254 e a inclusão do artigo 254-A e a ausência do tag along. Trata-se de outra interpretação que utiliza bases equivocadas, pois a Lei 9.467/97, que extinguiu o artigo 254, extinguiu diversos outros direitos dos minoritários, e representou um enfraquecimento geral dos seus direitos. Nesta mesma linha, a Lei n. 10.303/01 representou um fortalecimento dos minoritários, incluindo diversos outros direitos além do retorno do tag along. Tendo em vista o conjunto de direitos que foram extintos e, posteriormente, incluídos, não procede qualquer interpretação que se baseie nessa associação.

${ }^{129}$ DICK, Alexander; ZINGALES, Luigi, op. cit. A título de exemplo, os Estados Unidos e a Suíça, que não prevêem a obrigação de realização de OPA, têm uma baixa média de valor de prêmio em relação ao valor das ações no mercado ( $2 \%$ e $6 \%$, respectivamente), o que nos permite concluir que suas legislações impedem substancialmente a extração de benefícios privados.
} 
A presunção de que alienações de controle constituem, em si, um prejuízo aos minoritários, também se fragiliza diante destas conclusões. Num sistema legal desenvolvido, adquirentes de controle de má-fé deverão ter suas condutas lapidadas pelas regras do sistema ou, caso pratiquem alguma conduta contrária aos interesses sociais ou dos minoritários, deverão sofrer as devidas sanções.

Além disso, a obrigação de realizar oferta pública reduz os incentivos para que acionistas assumam os ônus que caracterizam a posição de controlador e reduz o interesse das companhias em recorrer ao mercado de capitais.

Verifica-se, assim, que a preocupação com a justiça distributiva ${ }^{130}$ acaba por frustrar a eficiência alocativa dos recursos, coibindo 0 desenvolvimento do mercado de capitais, em vez de promovê-lo, e se demonstrando mais prejudicial do que benéfico aos próprios minoritários. ${ }^{131}$

Por outro lado, se deixado nas mãos do mercado, o tag along pode ser fundamental para que as partes cheguem a uma situação que seja ótima para os seus interesses (como ocorre nos Estados Unidos e na Suíça).

A título de exemplo, numa hipótese em que a pessoa do acionista controlador seja relevante para o negócio, a possibilidade de sua saída poderia resultar num desconto do preço pelo qual este investidor está disposto a pagar pelas ações daquela companhia. Nestes casos, os minoritários podem negociar a inclusão de uma cláusula que preveja o tag along, ou outros direitos, em troca de um pagamento maior pelas ações.

\footnotetext{
${ }^{130}$ Cabe mencionar a observação de RACHEL SZTAJN: “dizer mais eficiente não quer dizer que a redistribuição dos bens via mercados seja mais justa ou que faça justiça distributiva, mas apenas significa que os bens, ao circularem entre pessoas, são transferidos para as que lhes atribuem maior valor, (entenda-se valor de troca), com o que se aumenta seu grau de satisfação ou de bem-estar" (Op. cit. p. 33).

${ }^{131}$ SEPE, Simone, Op. cit., p. 24-5.
} 
Há, por outro lado, situações em que uma cláusula como esta seria inútil na avaliação dos acionistas, ou em que os acionistas simplesmente prefiram pagar menos considerando a hipótese de uma eventual alienação de controle. Nestas hipóteses, a inclusão deste mecanismo oneraria as partes desnecessariamente e, ademais, dificultaria (ou, em alguns casos, impediria) que as partes, de comum acordo, chegassem a uma solução ótima conforme suas peculiaridades, impedindo a alocação eficiente dos recursos.

Diante destas considerações, a inclusão na LSA de uma regra como o tag along, excessivamente ampla, não corresponde à diversidade que caracteriza as companhias, constituindo-se num custo de transação. Além disso, os ganhos dessa intervenção não compensam as suas deficiências, levando-nos a concluir que uma opção mais eficiente ao mercado seria deixar que as forças do mercado encontrassem livremente as compensações que sejam adequadas aos seus interesses e às suas peculiaridades, o que, por conseguinte, contribuiria para um avanço no desenvolvimento econômico e social. 


\section{CONCLUSÃO}

A regulação econômica tem por finalidade reduzir os custos de transação e induzir a uma alocação ótima dos recursos, que leve em conta a eficiência e a eqüidade de acordo com os interesses sociais.

Em última análise, a busca pela eficiência na alocação dos recursos visa impulsionar o desenvolvimento econômico, ao reduzir os custos internos de produção, e elevar a produtividade e o nível de competitividade da economia brasileira.

Contudo, muitas vezes, as forças do mercado guiadas pela mão invisível serão capazes de produzir resultados mais eficientes do que intervenções do Estado.

Neste sentido, adverte RENÊ GARCIA JR. que "deficiências regulatórias são consideradas custos de transação ou falhas de mercado, podendo colaborar para a consolidação ou o esvaziamento de mercados inteiros". 132

A sociedade anônima, fruto da criação humana, foi desenvolvida com o objetivo de instituir um ambiente institucional favorável à atividade produtiva e, por constituir um dos alicerces do progresso econômico, o equilíbrio entre intervenção e laissez-faire deve também permear o ambiente regulatório que preside o seu desenvolvimento.

É nesse sentido que deve ser interpretada a exposição de motivos da LSA, a qual deixa claro que se tinha por intenção a criação de uma estrutura

\footnotetext{
${ }^{132}$ Os fundamentos econômicos para uma teoria da regulação em mercados de capitais em processo de globalização. Disponível em: <http://www.cvm.gov.br/port/public/publ/revista/arquivos/fundamentos.pdf>. Acesso em $28 \mathrm{de}$ maio de 2009.
} 
jurídica voltada para o fortalecimento do mercado de capitais, direcionando a poupança voluntária para o setor produtivo. Para tanto, menciona ser imprescindível o estabelecimento de uma sistemática que assegure ao minoritário o respeito a regras definidas e eqüitativas a fim de oferecer atrativos suficientes de segurança e rentabilidade, sem com isto imobilizar o empresário em suas iniciativas.

A exposição de motivos encontra-se em perfeita conformidade com as noções descritas acima. Para o progresso econômico é imperiosa a criação de um ambiente em que empresários tenham incentivos para desenvolver suas atividades e que investidores tenham incentivos para direcionarem suas poupanças para o setor produtivo, reduzindo os custos de captação de recursos.

Diante disto, a LSA pode desempenhar um relevante papel neste processo, sendo essencial que seus dispositivos se alinhem às finalidades que lhes deram origem.

O artigo 254-A da LSA busca proteger os acionistas minoritários, estabelecendo a obrigação de o adquirente realizar oferta pública para a aquisição das ações minoritárias por, pelo menos, o equivalente a $80 \%$ do preço pago pelas ações do bloco de controle.

Como cremos ter sido demonstrado, o referido artigo não apenas falha em proteger os minoritários, como ainda possui diversas ineficiências que em muito superam eventuais ganhos a ele imputáveis.

Evidenciou-se que o artigo 254-A não é um meio adequado para coibir a extração de benefícios privados, que subtraem valor do minoritário, na condução dos negócios. Uma opção mais eficiente para atender este fim, seria a fixação de regras que coíbam estas condutas diretamente, ou de 
regras gerais sobre a conduta dos controladores e administradores (modelo americano), associadas a regras de transparência e mecanismos de fiscalização (enforcement).

Ademais, ao exigir o compartilhamento do prêmio, elimina-se um poderoso incentivo para se garantir a presença positiva do controlador, prêmio este que se afigura proporcional aos ônus de sua posição e de suas responsabilidades.

Outrossim, o argumento de que o artigo 254-A da LSA justificaria o trade-off entre as transferências de controle para controladores "com espírito aproveitador" e as transferências eficientes filtradas, não resistiu às demonstrações das ineficiências da referida norma. Nesse sentido, diversos estudos demonstram que, em geral, as alienações de controle agregam valor às ações da companhia. Parte-se, portanto, de uma presunção equivocada de que alienações de controle são prejudiciais aos minoritários. Assim, ao impedir a concretização de operações que, em seu valor agregado, atingiriam um resultado mais eficiente que na ausência da previsão legal do tag along, tanto as companhias, como os minoritários serão prejudicados por esta intervenção, no devido prazo. Destaca-se, ainda, que o tag along dificulta a transferência do controle exercido por um acionista "com espírito aproveitador" para um controlador mais eficiente, especialmente no Brasil, em que a média do valor do prêmio é bastante elevada.

Da mesma forma, o argumento de que se deveria garantir um direito de retirada aos minoritários, por existir uma relação intuitu personae, não encontra sustentação para justificar a intervenção estatal.

Além disso, o tag along poderá causar desequilíbrios no mercado, como a distorção na escolha da estrutura ótima de capital das companhias, e 
o menor interesse das companhias fechadas em se financiarem no mercado de capitais.

Em vista disso, podemos concluir que o tag along previsto pelo artigo 254-A da LSA não atinge seus objetivos e não corresponde à diversidade das companhias abertas, constituindo-se numa intervenção ineficiente e representando um custo de transação nas relações entre os agentes econômicos.

Portanto, impõe-se a superioridade da opção mais eficiente e mais adequada ao funcionamento dos mercados, que consiste na livre busca do justo equilíbrio entre as partes das negociações, atendendo às peculiaridades dos agentes econômicos e das circunstâncias concretas das transações o que, conseqüentemente, contribuiria de forma mais efetiva para um avanço no desenvolvimento econômico e social. 


\section{Referências Bibliográficas}

AFONSO, António.; SCHUKNECHT, Ludger, TANZI, Vito, Public sector efficiency: an international comparison. Disponível em: <http://www.ecb.int/pub/pdf/scpwps/ecbwp242.pdf>. Acesso em 20 de abril de 2009.

ANDERSON, Ronald C.; MANSI, Satar A.; REEB, David M., Founding Family Ownership and the Agency Cost of Debt. Disponível em: $<$ http://papers.ssrn.com/sol3/papers.cfm?abstract_id=303864>. Acesso em 2 de junho de 2009.

ANDERSON, Ronald C.; REEB, David M., Founding-Family Ownership, Corporate Diversification, and Firm Leverage. Disponível em: $<$ http://papers.ssrn.com/sol3/papers.cfm?abstract_id=462541>. Acesso em 2 de junho de 2009.

.Who monitors the family?. Disponível em:

<http://papers.ssrn.com/sol3/papers.cfm?abstract_id=369620>, 2003b, Founding Family Ownership and Firm Performance: Evidence from the S\&P 500. Disponível em:

$<$ http://papers.ssrn.com/sol3/papers.cfm?abstract_id=365260>. Acesso em 2 de junho de 2009.

Board Composition: Balancing Family Influence in S\&P 500

Firms. Disponível em:

<http://papers.ssrn.com/sol3/papers.cfm?abstract_id=590305>. Acesso em 2 de junho de 2009.

ANDREWS, William, The Stockholder's Right to Equal Opportunity in the Sale of Shares, Harvard Law Review, n. 3, 1965.

ANDREZO, Andrea Fernandes. A alienação de controle de companhia aberta e a recente reforma da legislação societária - efetivo avanço? Revista de Direito Mercantil, Industrial, Econômico e Financeiro n. 130, Malheiros Editores: 2003.

ARAGÃO, Alexandre Santos de. Agências Reguladoras e a Evolução do Direito Administrativo Econômico. Rio de Janeiro: Forense, 2006.

ÁVILA, Humberto Bergmann. Repensando o "Princípio da Supremacia do Interesse Público sobre o Particular. Disponível em: <http://www.direitodoestado.com/revista/RERE-11-SETEMBRO-2007HUMBERTO\%20AVILA.pdf>. Acesso em 15 de abril de 2009. 
BARCLAY, Michael J.; e HOLDERNESS Clifford G., The Law and Large-Block Trades, Journal of Law \& Economics, 1992, vol. 35, Issue 2, pages 265-94.

BEBCHUK, Lucian Arye, A Rent-Protection Theory Of Corporate Ownership And Control. Disponível em:

$<$ http://papers.ssrn.com/sol3/papers.cfm?abstract_id=168990>. Acesso em 21 de abril de 2009.

Efficient and inefficient sales of corporate control. Disponível em: $<$ http://papers.ssrn.com/sol3/papers.cfm?abstract_id=520943>. Acesso em 2 de junho de 2009.

BITTLINGMAYER, George. The Market for Corporate Control (Including Takeovers), Disponível em:

<http://papers.ssrn.com/sol3/papers.cfm?abstract_id=81808>. Acesso em 03 de junho de 2009.

BLACK, Bernard, Streghening Brazil's Security Markets, Revista de Direito Mercantil, vol. 120, 2000.

BULGARELLI, Waldírio, Regime Jurídico da Proteção às Minorias nas S/A, Rio de Janeiro, Renovar, 1998.

BURKI, Shahid; PERRY Guillermo, Beyond the Washington consensus: institutions matter, Washington, World Bank Publications, 1998.

CANTIDIANO, Luiz Leonardo. Estudos de direito societário. Rio de Janeiro: Renovar, 1999.

Alienação e aquisição de controle. Revista de Direito Mercantil, Industrial, Econômico e Financeiro n. 59. Malheiros Editores: 1985.

CARVALHOSA, Modesto e EIZIRIK, Nelson. A Nova Lei das Sociedades Anônimas. São Paulo: Saraiva. 2002.

CARVALHOSA, Modesto. Comentários à Lei de Sociedades Anônimas: Lei $n^{\circ}$ 6.404, de 15 de dezembro de 1976. São Paulo: Saraiva. 1998. Vol. 4, Tomo II.

A Nova Lei das Sociedades Anônimas, Rio de Janeiro, Ed. Paz e Terra. 1976.

CLEMENTE JUNIOR, José Alberto. Oferta pública de aquisição de ações na alienação de controle de companhias abertas. Revista de Direito 
Mercantil, Industrial, Econômico e Financeiro n. 129. Malheiros Editores: 2003.

COASE, Ronald H., The Problem of Social Cost. Disponível em:

<http://www.sfu.ca/ allen/CoaseJLE1960.pdf>. Acesso em 15 de abril de 2009.

The Problem of Social Cost. Disponível em:

<http://www.sfu.ca/ allen/CoaseJLE1960.pdf>. Acesso em 01 de junho de 2009.

The Nature of the Firm. Disponível em:

<http://www.scribd.com/doc/2530438/COASEThe-Nature-of-the-Firm>.

Acesso em 01 de junho de 2009.

COMPARATO, Fábio Konder, Aspectos Jurídicos da Macroempresa, São Paulo, Editora Revista dos Tribunais, 1970.

Direito empresarial: estudos e pareceres. São Paulo: Saraiva, 1990

COMPARATO, Fábio Konder; SALOMÃO FILHO, Calixto. O poder de controle na sociedade anônima. $5^{\mathrm{a}} \mathrm{ed}$. Rio de Janeiro: Editora Forense. 2008.

COSTA, Carlos Celso Orcesi da., Controle externo nas companhias. Revista de Direito Mercantil, Industrial, Econômico e Financeiro n. 44. Revista dos Tribunais. 1981.

DEMSETZ, Harold; LEHN, Kenneth, The Structure of Corporate Ownership: Causes and Consequences. Disponível em: <http://astro.temple.edu/ tub06197/Wk7Demsetz_Lehn_JPE1985.pdf>. Acesso em 4 de junho de 2009.

DICK, Alexander; ZINGALES, Luigi, Private Benefits of Control: An International Comparison. Disponível em: <http://papers.ssrn.com/sol3/papers.cfm?abstract_id=296107>. Acesso em 2 de março de 2009.

EDWARDS, Jeremy; WEICHENRIEDER, Alfons, Ownership Concentration And Share Valuation: Evidence From Germany, Working Paper N. 193, 1999. Disponível em: <http://papers.ssrn.com/sol3/papers.cfm?abstract_id=272627>. Acesso em 27 de maio de 2009. 
EIZIRIK, Nelson. Temas de direito societário. Rio de Janeiro: Renovar. 2005.

Questões de direito societário e mercado de capitais, Rio de Janeiro, Ed. Forense, 1987.

EIZIRIK, Nelson; GAAL, Ariádna B.; PARENTE, Flávia; HENRIQUES, Marcus de Freitas. Mercado de Capitais - regime jurídico. Renovar. Rio de Janeiro, 2008.

GARCIA JR., Renê, Os fundamentos econômicos para uma teoria da regulação em mercados de capitais em processo de globalização.

Disponível em:

<http://www.cvm.gov.br/port/public/publ/revista/arquivos/fundamentos.pdf $>$. Acesso em 28 de maio de 2009.

GERSHON, Peter, Gershon Efficiency Review, 2004-5.

GILSON, Ronald; e GORDON, Jeffrey, Controlling Controlling Shareholders. Disponível em: <http://papers. ssrn.com/abstract=417181>. Acesso em 5 de fevereiro de 2009.

GLAESER, Edward, LA PORTA, Rafael, SILANES, Florêncio Lopez de, e SHLEIFER Andrei, Do institutions cause growth?, Disponível em: <http://papers.ssrn.com/sol3/papers.cfm?abstract_id=556370>. Acesso em 2 de abril de 2009.

GORGA, Erica, Análise da Eficiência de Normas Societárias: Emissão de Preferenciais, Tag Along e Composição do Conselho Fiscal. Disponível em; $<$ http://repositories.cdlib.org/cgi/viewcontent.cgi?article $=1079 \&$ context $=b p$ le>. Acesso em 5 maio de 2009.

GROSSMAN, Sanford J., HART, Oliver D., Takeover bids, the free-rider problem, and the theory of corporation. Disponível em:

<http://www.jstor.org/pss/3003400>. Acesso em 03 de junho de 2009.

The Allocational Role of Takeover Bids in Situations of Asymmetric Information, Rodney L. White Center for Financial Research, University of Pennsylvania, January 1980.

HANSMANN, Henry; KRAAKMAN, Reinier. What is Corporate Law?, Yale Law School, Center for Law, Economics and Public Policy, Research Paper n. 300. Disponível em:

<http://papers.ssrn.com/sol3/papers.cfm?abstract_id=568623>. Acesso em 01 de junho de 2009. 
HART, Oliver. Norms and the Theory of the Firm. Disponível em: <http://www.law.harvard.edu/programs/olin_center/papers/pdf/326.pdf>. Acesso em 01 de junho de 2009.

HOLDERNESS Clifford G., A Survey of Blockholders and Corporate Control. Disponível em: <http://papers.ssrn.com/sol3/papers.cfm?abstract_id=281952>. Acesso em 4 de junho de 2009.

JENSEN, Michael C., Corporate Control and the Politics Of Finance. Disponível em:

$<$ http://papers.ssrn.com/sol3/papers.cfm?abstract_id=350421>. Acesso em 03 de junho de 2009.

JENSEN, Michael C.; MECKLING, William H., Theory of the Firm: Managerial Behavior, Agency Costs and Ownership Structure. Disponível em: <http://papers.ssrn.com/sol3/papers.cfm?abstract_id=94043>. Acesso em 5 de fevereiro de 2009.

JOSUÁ, Adriana. Alienação do controle de s.a. por oferta pública (art. 254A da Lei das S.A.). Revista de Direito Mercantil, Industrial, Econômico e Financeiro n. 126. Malheiros Editores: 2002.

JR. COFFEE, John C. Do Norms Matter?: A Cross-Country Examination of the Private Benefits of Control. Disponível em:

<http://papers.ssrn.com/sol3/papers.cfm?abstract_id=257613>. Acesso em 03 de junho de 2009.

JR. OLSON, Mancur. Distinguished Lecture on Economics in Government, Big Bills Left on the Sidewalk: Why Some Nations are Rich, and Others Poor. Disponível em: <http://www.ambertrust.com/assets/MancurOlson_on_Transition_Econ_7 32003152238.pdf>. Acesso em 03 de junho de 2009.

KARL, Hoffstein, One Size Does Not Fit All: Corporate Governance for 'Controlled Companies'. Disponível em:

$<$ http://papers.ssrn.com/sol3/papers.cfm?abstract_id=802705>. Acesso em 5 de abril de 2009.

LA PORTA, Rafael, LOPEZ-DE-SILANES, Florêncio, SHLEIFER, Andrei, VISHNY, Robert W. Investor Protection: Origins, Consequences, Reform. Disponível em: <http://www1.worldbank.org/finance/assets/images/Fs01_web1.pdf>. Acesso em 03 de junho de 2009. 
LA PORTA, Rafael, LOPEZ-DE-SILANES, Florêncio, SHLEIFER, Andrei, VISHNY, Legal Determinants of External Finance. Disponível em: $<$ http://www.nber.org/papers/w5879.pdf?new_window=1>. Acesso em 2 de junho de 2009.

LAMY FILHO, Alfredo, A Reforma da Lei das Sociedades Anônimas, de 1972.

LAMY FILHO, Alfredo; PEDREIRA, José Luiz Bulhões. A lei das S.A. (pressupostos, elaboração, aplicação). Rio de Janeiro: Renovar, v.1 e v. 2, 1997.

LOBO, Jorge (Coordenador). Reforma da Lei das Sociedades Anônimas: inovações e questões controvertidas da Lei $n^{o} 10.303$, de 31.10.2001. Rio de Janeiro: Forense, 2002.

Interpretação realista da alienação de controle de companhia aberta. Revista de Direito Mercantil, Industrial, Econômico e Financeiro n. 123. Malheiros Editores: 2001.

MANDL, Ulrike, DIERX, Adriaan, ILZKOVITZ, Fabienne, The efficiency and effectiveness of public spending. Disponível em:

$<\mathrm{http}$ ///ec.europa.eu/economy_finance/publications/publication11902_en.p df $>$. Acesso em 20 de abril de 2009.

MANKIW, N. Gregory, Introdução à economia: princípios de micro e macroeconomia, Rio de Janeiro, Campus, 1999.

MARQUES NETO, Floriano Peixoto de Azevedo. Limites à Abrangência e à Intensidade da Regulação Estatal. Disponível em:

<http://www.direitodoestado.com/revista/REDAE-4-NOVEMBRO-2005FLORIANO_AZEVEDO.pdf $>$. Acesso em 5 de abril de 2009.

MOREIRA, Vital. Auto-regulação Profissional e Administração Pública, Coimbra: Almedina, 1997.

MOTTA, Nelson Cândido. Alienação e titularidade do poder de controle nas companhias abertas - Notas sobre a transferência de ações entre participantes do grupo controlador e sobre a interpretação do art. 254 da Lei das S.A., Revista Forense volume 324, out-dez/1993.

MURPHY, Warren, Efficiency (and effectiveness) in the public sector, Nova Zelândia, 2007. Disponível em: $<$ http://www.conferenz.co.nz/efficiency-and-effectiveness-in-the-publicsector-2.html>. Acesso em 20 de abril de 2009. 
NEVONA, Tatiana. Control Values and Changes in Corporate Law in Brazil. Disponível em:

<http://papers.ssrn.com/sol3/papers.cfm?abstract_id=294064>. Acesso em 03 de junho de 2009.

NORTH, Douglass C. The New Institutional Economics and Development, Washington University. Disponível em:

<http://www.econ.iastate.edu/tesfatsi/NewInstE.North.pdf>. Acesso em 03 de junho de 2009.

. Understanding the Process of Economic Change, New Jersey, Princeton University Press, 2005.

. Institutions, Institutional Change and Economic Performance, Cambridge University Press, New York, 1990.

OLSON, Mancur, Distinguished lecture on Economics in government. Big bills left on the sidewalk: why some nations are rich, and others poor. Disponível em:

<http://www.fbird.com/assets/MancurOlson_on_Transition_Econ_732003 152238.pdf>. Acesso em 5 de abril de 2009.

PENTEADO, Mauro Rodrigues. Apontamentos sobre a alienação do controle de companhias abertas. Revista de Direito Mercantil, Industrial, Econômico e Financeiro n. 76. Malheiros Editores: 1989.

PINHEIRO, Armando Castelar; SADDI, Jairo, Direito, Economia e Mercados, Rio de Janeiro, Elsevier, 2005, 2ª reimpressão.

POSNER, Richard A. Theories of Economic Regulation. Disponível em: <http://www.nber.org/papers/w0041.pdf>. Acesso em 01 de junho de 2009.

The Problem of Social Cost. Disponível em:

<http://www.sfu.ca/ allen/CoaseJLE1960.pdf>. Acesso em 4 de junho de 2009.

Economic Analysis of Law, Editorial Advisory Board, 1992.

POULSEN, Thomas. Private benefits in corporate control transactions. Disponível em: <http://research.asb.dk/fbspretrieve/1356/F-2008-03 >. Acesso em 03 de junho de 2009.

PRADO, Roberta Nioac. Da obrigatoriedade por parte do adquirente do controle de sociedade por ações de capital aberto de fazer simultânea oferta pública em iguais condições aos minoritários - art. 254 da Lei 6.404/76 - É efetivo mecanismo de proteção aos minoritários? Revista de Direito 
Mercantil, Industrial, Econômico e Financeiro n. 106. Malheiros Editores: 1997.

REQUIÃO, Rubens. Curso de direito comercial. $35^{\mathrm{a}}$ ed. São Paulo: Saraiva, v. 2, 2007.

SCHWARTZ, Lawrence, Cost-Benefit Analysis in Canadian Securities Regulation. Disponível em: $\langle$ http://www.tfmsl.ca/docs/V4(6)\%20Schwartz.pdf〉. Acesso em 5 de abril de 2009.

SHLEIFER, Andrei, VISHNY, Robert W. Large Shareholders and Corporate Control. Disponível em: $<$ http://www.economics.harvard.edu/faculty/shleifer/files/lg_shareholders.p df $>$. Acesso em 03 de junho de 2009.

SIQUEIRA, Carlos Augusto Junqueira de. Transferências do Controle Acionário - Interpretação e Valor. Niterói: FMF. 2004.

SKOG, Rolf, Does Sweeden Need a Mandotory Bid Rule?. Disponível em: $<$ http://www.suerf.org/download/studies/study2.pdf >. Acesso em 5 de maio de 2009.

STIGLER, George, Law or Economics?. Disponível em: <http://www.jstor.org/pss/725548>. Acesso em 4 de junho de 2009.

SZTAJN, Rachel. Teoria Jurídica da Empresa. Atividade Empresária e Mercados. São Paulo: Atlas, 2004.

TESTA, Pedro. The Mandatory Bid Rule in the European Community and in Brazil: A Critical View, Disponível em: <http://papers.ssrn.com/sol3/papers.cfm?abstract_id=943089>. Acesso em 3 de fevereiro de 2009.

UBIRATAN, Iorio J., "Falhas de Mercado" versus Falhas de Governo. Disponível em: 〈http://www.ubirataniorio.org/material.htm〉. Acesso em 30 de março de 2009.

WALD, Arnoldo. Do descabimento da oferta pública de compra em relação às ações preferenciais. Revista de Direito Mercantil, Industrial, Econômico e Financeiro n. 45. Malheiros Editores: 1982.

YAMASHITA, Douglas. Dos destinatários da oferta pública na alienação de controle de companhia aberta. Revista de Direito Mercantil, Industrial, Econômico e Financeiro n. 131. Malheiros Editores: 2003. 
ZYLBERSZTAJN, Decio e SZTAJN, Rachel, Direito \& Economia :

Análise Econômica do Direito e das Organizações, Organização, Rio de Janeiro, Ed. Elsevier, 2005 